\title{
Dietary Vitamin D Increases Percentages and Function of Regulatory $T$ Cells in the Skin-Draining Lymph Nodes and Suppresses Dermal Inflammation
}

\author{
Shelley Gorman, Sian Geldenhuys, Melinda Judge, Clare E. Weeden, \\ Jason Waithman, and Prue H. Hart \\ Telethon Kids Institute, University of Western Australia, Perth, WA, Australia \\ Correspondence should be addressed to Shelley Gorman; shelley.gorman@telethonkids.org.au
}

Received 12 June 2016; Revised 4 August 2016; Accepted 17 August 2016

Academic Editor: Manoj K. Mishra

Copyright (c) 2016 Shelley Gorman et al. This is an open access article distributed under the Creative Commons Attribution License, which permits unrestricted use, distribution, and reproduction in any medium, provided the original work is properly cited.

\begin{abstract}
Skin inflammatory responses in individuals with allergic dermatitis may be suppressed by dietary vitamin $\mathrm{D}$ through induction and upregulation of the suppressive activity of regulatory $\mathrm{T}\left(\mathrm{T}_{\mathrm{Reg}}\right)$ cells. Vitamin $\mathrm{D}$ may also promote $\mathrm{T}_{\text {Reg }}$ cell tropism to dermal sites. In the current study, we examined the capacity of dietary vitamin $\mathrm{D}_{3}$ to modulate skin inflammation and the numbers and activity of $\mathrm{T}_{\mathrm{Reg}}$ cells in skin and other sites including lungs, spleen, and blood. In female BALB/c mice, dietary vitamin $\mathrm{D}_{3}$ suppressed the effector phase of a biphasic ear swelling response induced by dinitrofluorobenzene in comparison vitamin $\mathrm{D}_{3}$-deficient female $\mathrm{BALB} / \mathrm{c}$ mice. Vitamin $\mathrm{D}_{3}$ increased the percentage of $\mathrm{T}_{\mathrm{Reg}}(\mathrm{CD} 3+\mathrm{CD} 4+\mathrm{CD} 25+$ Foxp3+) cells in the skin-draining lymph nodes (SDLN). The suppressive activity of $\mathrm{T}_{\text {Reg }}$ cells in the SDLN, mesenteric lymph nodes, spleen, and blood was upregulated by vitamin $\mathrm{D}_{3}$. However, there was no difference in the expression of the naturally occurring $\mathrm{T}_{\mathrm{Reg}}$ cell marker, neuropilin, nor the expression of CCR4 or CCR10 (skin-tropic chemokine receptors) on $\mathrm{T}_{\text {Reg }}$ cells in skin, SDLN, lungs, and airway-draining lymph nodes. These data suggest that dietary vitamin $\mathrm{D}_{3}$ increased the percentages and suppressive activity of $\mathrm{T}_{\text {Reg }}$ cells in the SDLN, which are poised to suppress dermal inflammation.
\end{abstract}

\section{Introduction}

Vitamin D plays an intrinsic role in shaping innate and adaptive immune responses $[1,2]$. Vitamin $\mathrm{D}$ is produced following skin exposure to ultraviolet B photons of sunlight, resulting in the conversion of the precursor 7-dehydrocholesterol into vitamin $\mathrm{D}_{3}$, which can also be acquired through dietary supplementation. The vitamin D-binding protein (VDBP) transports much of this vitamin $\mathrm{D}_{3}$ into the liver, where a hydroxylation reaction converts vitamin $\mathrm{D}_{3}$ into 25-hydroxyvitamin $\mathrm{D}_{3}\left(25(\mathrm{OH}) \mathrm{D}_{3}\right)$. This form of vitamin $\mathrm{D}_{3}$ is found at nanomolar levels in blood, and because of its relative stability and longer half-life, it is used as a measure of vitamin D sufficiency, with $50 \mathrm{nM}$ currently considered the tipping point for insufficiency by the National Institute of Health [3] (although this remains controversial [4]). In renal proximal tubule epithelial cells, and other cells including disease-activated macrophages (reviewed in [5]), $25(\mathrm{OH}) \mathrm{D}_{3}$ is converted into the most active vitamin $\mathrm{D}$ metabolite, 1,25-dihydroxyvitamin $\mathrm{D}_{3}\left(1,25(\mathrm{OH})_{2} \mathrm{D}_{3}\right)$. It is this form of vitamin $\mathrm{D}_{3}$ which has the most potent effects on regulating immune responses, with circulating levels in the picomolar range $[1,6]$.

Central to the ability of $1,25(\mathrm{OH})_{2} \mathrm{D}_{3}$ to modulate immune responses are changes to regulatory $\mathrm{T}$ cells $\left(\mathrm{T}_{\mathrm{Reg}}\right.$ cells) and dendritic cells (DCs) [7]. Topical (skin) application of $1,25(\mathrm{OH})_{2} \mathrm{D}_{3}$ enhanced the suppressive capacity $[8,9]$ and proliferative activity [10] of CD4+CD25+Foxp3+ $\mathrm{T}_{\mathrm{Reg}}$ cells. Stimulation of DCs with bacterial products like lipopolysaccharide or cytokines like transforming growth factor- $\beta$ may result in the synthesis of $1,25(\mathrm{OH})_{2} \mathrm{D}_{3}$ from circulating $25(\mathrm{OH}) \mathrm{D}_{3}$, promoting $\mathrm{T}_{\text {Reg }}$ cell activity (reviewed in $[1,2]$ ). The VDBP may also play an important role in this process, whereby high affinity VDBP can prevent conversion of $25(\mathrm{OH}) \mathrm{D}_{3}$ to $1,25(\mathrm{OH})_{2} \mathrm{D}_{3}$ by DCs and thus their ability to modulate $\mathrm{T}_{\text {Reg }}$ cell activity [11]. With the right costimulators, 
including interleukin-2, $1,25(\mathrm{OH})_{2} \mathrm{D}_{3}$ can modulate the suppressive functions of $\mathrm{T}_{\text {Reg }}$ cells independently of DCs [12].

While the capacity for $1,25(\mathrm{OH})_{2} \mathrm{D}_{3}$ to regulate adaptive immunity through its effects on $\mathrm{T}_{\text {Reg }}$ cells and DCs is clear, most studies have used supraphysiological levels of $1,25(\mathrm{OH})_{2} \mathrm{D}_{3}(\geq 10 \mathrm{nM})$. During monocyte differentiation into macrophages, increased concentrations of $1,25(\mathrm{OH})_{2} \mathrm{D}_{3}$ (up to $1 \mathrm{nM}$ ) were detected in cell culture media, but this was not observed during monocyte differentiation to DCs [13]. This increased production of $1,25(\mathrm{OH})_{2} \mathrm{D}_{3}$ could have paracrine effects on colocated DCs [13] and T cells [14]. However, most in vitro studies have used substantially more $1,25(\mathrm{OH})_{2} \mathrm{D}_{3}(\geq 10 \mathrm{nM})$ to modulate $\mathrm{DC}$ and T cell phenotype and function. $\mathrm{T}_{\mathrm{Reg}}$ cell numbers and/or their suppressive activity correlate with circulating $25(\mathrm{OH}) \mathrm{D}_{3}$ levels. This has been observed in patients with pancreatitis [6], multiple sclerosis [15], and asthma [16, 17] or those chronically infected with the hepatitis $C$ virus [18]. Supplementation with vitamin $\mathrm{D}_{3}$ or an analogue increased $\mathrm{T}_{\text {Reg }}$ cell numbers in healthy individuals (140,000 IU oral vitamin $\mathrm{D}_{3}$ /month) [19] or patients with undifferentiated connective tissue disease $(0.5 \mu \mathrm{g}$ oral alfacalcidol/day) [20]. Other studies report a positive correlation between serum $1,25(\mathrm{OH})_{2} \mathrm{D}_{3}$ levels (but not $25(\mathrm{OH}) \mathrm{D}_{3}$ levels) and circulating $\mathrm{T}_{\mathrm{Reg}}$ cell numbers in patients with multiple sclerosis [21]. A negative correlation between $25(\mathrm{OH}) \mathrm{D}_{3}$ and $\mathrm{T}_{\mathrm{Reg}}$ cell numbers has been reported in cord blood [22]. Most studies support a positive relationship between circulating $25(\mathrm{OH}) \mathrm{D}_{3}$ levels and $\mathrm{T}_{\text {Reg }}$ cell activity; however, this has not always been associated with improved disease-related outcomes [15, 19].

Another intriguing aspect of vitamin D biology includes its ability to modulate the tropism of cells for certain tissues. Tropism for skin has been suggested in some studies, where $1,25(\mathrm{OH})_{2} \mathrm{D}_{3}$ or an analogue ( $\mathrm{nM}$ range) increased the expression of the skin-tropic chemokine receptor CCR10 on cultured $\mathrm{T}$ cells $[14,23]$. The $1,25(\mathrm{OH})_{2} \mathrm{D}_{3}$ analogue TX527 significantly upregulated other skin-homing molecules like CCR4 (but not CLA) on T cells, as well as inflammationhoming molecules (e.g., CCR5, CXCR3, and CXCR6) but downregulated expression of lymph node-homing molecules (CD62L, CCR7, and CXCR4) [23]. Serum 25(OH) $\mathrm{D}_{3}$ levels are associated with increased expression of the skin-tropic chemokine receptors CCR 4 and CLA on circulating $\mathrm{T}_{\text {Reg }}$ cells from healthy male volunteers [24]. Other studies in HIVinfected participants suggested that serum $25(\mathrm{OH}) \mathrm{D}_{3}$ was negatively associated with CCR4 expression on circulating $\mathrm{T}_{\text {Reg }}$ cells. Vitamin $\mathrm{D}_{3}$ supplementation (25,000 IU/week) of these participants increased CCR4 and CCR10 expression on blood $\mathrm{T}_{\text {Reg }}$ cells [25]. Collectively, these studies suggest that $1,25(\mathrm{OH})_{2} \mathrm{D}_{3}$ promotes homing of $\mathrm{T}_{\text {Reg }}$ cells towards skin or sites of inflammation.

The results of a recent meta-analysis of clinical trials suggest that dietary vitamin $\mathrm{D}_{3}$ supplementation may reduce symptoms of atopic dermatitis [26], an inflammatory skin disease. In this study, we investigated how the tissue distribution and suppressive function of $\mathrm{T}_{\text {Reg }}$ cells are regulated by dietary vitamin $\mathrm{D}_{3}$. We used a murine model of dietaryinduced vitamin $D_{3}$ restriction to induce vitamin $D_{3}$ deficiency and compared the effects of dietary vitamin $\mathrm{D}_{3}$ on
$\mathrm{T}_{\text {Reg }}$ cell function and numbers in various tissues and skin inflammation induced by a hapten.

\section{Materials and Methods}

2.1. Mice and Diet. All experiments were performed according to the ethical guidelines of the National Health and Medical Research Council of Australia and with approval from the Telethon Kids Institute Animal Ethics Committee (AEC\#229). BALB/c mice were purchased from the Animal Resources Centre, Western Australia. Mice transgenic for the $\mathrm{OVA}_{323-339}$-specific (ISQAVHAAHAEINEAGR) T cell receptor (DO11.10) on a $\mathrm{BALB} / \mathrm{c}$ background were originally purchased from the Jackson Laboratory and bred in-house. Expression of $\mathrm{OVA}_{323-339}$-specific $\mathrm{T}$ cell receptor on $\mathrm{T}$ cells from DO11.10 mice was confirmed as previously described [9]. Female 3-week-old BALB/c or DO11.10 transgenic mice were placed on semipure diets, which were supplemented with vitamin $\mathrm{D}_{3}$ (2280 IU vitamin $\mathrm{D}_{3} / \mathrm{kg}$ with $1 \%$ calcium, SF05-34, Specialty Feeds, Perth, Western Australia) or were not supplemented with vitamin $\mathrm{D}_{3}$ (0 IU vitamin $\mathrm{D}_{3} / \mathrm{kg}$ with $2 \%$ calcium, SF05-033, Specialty Feeds) as previously described [27, 28]. At 8 weeks of age, female mice were mated with adult male mice maintained on standard mouse chow (Specialty Feeds, containing $2000 \mathrm{IU}$ vitamin $\mathrm{D}_{3} / \mathrm{kg}$ ). Female or male offspring were maintained on the same vitamin $\mathrm{D}_{3}$ replete or vitamin $\mathrm{D}_{3}$-deficient diets (as their mothers) for the rest of the experiment. All results shown are for female offspring, unless otherwise stated.

2.2. Measurement of Serum 25-Hydroxyvitamin $D_{3}$ $\left(25(\mathrm{OH}) \mathrm{D}_{3}\right)$. Serum $25(\mathrm{OH}) \mathrm{D}_{3}$ levels were measured in $\mathrm{BALB} / \mathrm{c}$ mice using IDS EIA ELISA kits (Immunodiagnostic Systems Ltd., Fountain Hills, AZ) as described by the manufacturer (limit of detection was $7 \mathrm{nmol} \cdot \mathrm{L}^{-1}$ ). We have previously shown that results from this assay correlate highly $(r=0.99)$ [29] with a liquid chromatography-tandem mass spectrometry method, which has been certified to a reference measurement procedure developed by the National Institute of Standards and Technology and Ghent University [30, 31].

2.3. Biphasic Ear Swelling Assay. A biphasic ear swelling response [32,33] was induced by painting both sides of each ear pinnae with $10 \mu \mathrm{L}$ of $0.05-0.2 \%$ 2,4-dinitrofluorobenzene (DNFB, Sigma, St Louis, MO) in acetone using a micrometer to measure ear thickness in a blinded fashion at the indicated times. Results are shown as the change in ear thickness, with baseline measures subtracted from those measured at each time point.

2.4. Identification of $T_{\text {Reg }}$ Cells by Flow Cytometry. Single cell suspensions were generated from minced ear skin or whole lung digested for $90 \mathrm{~min}$ with collagenase IV $(3 \mathrm{mg} / \mathrm{mL}$, Worthington) at $37^{\circ} \mathrm{C}$ with frequent vortexing. To isolate peripheral blood mononuclear cells (PBMC), heparinized blood was diluted $1: 2$ in $0.9 \%$ saline (Baxter, Old Toongabbie, NSW, Australia) and layered over $1 \mathrm{~mL}$ Lymphoprep (Axis-Shield, Oslo, Norway) for every $2 \mathrm{~mL}$ of diluted blood. Samples were then centrifuged at $800 \times \mathrm{g}$ for $20 \mathrm{~min}$ at room temperature 
with PBMCs collected from the resulting interface. Skindraining lymph nodes (SDLN; brachial, inguinal, and axillary), airway-draining lymph node cells (ADLN; posterior mediastinal, tracheobrachial, and parathymic), mesenteric lymph nodes (MLN), or spleens were removed from mice and physically disaggregated to generate single cell suspensions as previously described [9]. Staining of surface (CD3, CD4, CD25, CCR4, CCR10, neuropilin, MHC class II, and CD11c) and intracellular (Foxp3) antigens was performed as previously described [9]. At least 10,000 cells of interest were collected using the FACS LSRII (BD Biosciences) flow cytometer. Data were analyzed using FlowJo software (v9.5.2, TreeStar Inc., Ashland, OR, USA).

2.5. Assessing the Suppressive Capacity of $T_{\text {Reg }}$ Cells. We isolated $\mathrm{T}_{\mathrm{Reg}}$ cells from vitamin $\mathrm{D}_{3}$-replete or vitamin $\mathrm{D}_{3}$ deficient DO11.10 mice to test the capacity of dietary vitamin $\mathrm{D}_{3}$ to modify the suppressive activity of cells located in a number of different immune sites. As the majority of $T_{R e g}$ cells express the $\mathrm{OVA}_{323-339}$ receptor [9], they will suppress the IL-2-secreting capacity of cocultured $\mathrm{OVA}_{323-339}$ receptor-specific $\mathrm{CD} 4+\mathrm{T}$ cells in the presence of antigenpresenting cells and $\mathrm{OVA}_{323-339}$ peptide, as we have demonstrated previously [9]. CD4+CD25+ cells $(\geq 95 \%$ pure, as determined by flow cytometry) were isolated from specified tissues of DO11.10 mice using a CD4+CD25+ regulatory $\mathrm{T}$ cell isolation kit (Miltenyi Biotec) or by cell sorting as previously described $[9,34]$. Greater than $90 \%$ of the purified CD4+CD25+ cells expressed Foxp3 (confirmed by flow cytometry). Peripheral lymph node cells (including SDLN, ADLN, MLN, auricular-draining lymph nodes, and paraaortic lymph nodes) of naïve DO11.10 mice were used as responder cells. These were resuspended in RPMI with 10\% FCS and $2 \mu \mathrm{M}$ 2-ME and aliquot into round-bottomed 96well plates at $10^{5}$ cells $/ 0.1 \mathrm{~mL} /$ well. CD $4+\mathrm{CD} 25+$ cells were added to responder cells at ratios of $1: 8,1: 16$, or $1: 32$. $\mathrm{OVA}_{323-339}$ peptide was added at a final concentration of $1 \mu \mathrm{g} / \mathrm{mL}$. After incubation for $92 \mathrm{~h}$ at $37^{\circ} \mathrm{C}$ in $5 \% \mathrm{CO}_{2}$, supernatants were harvested and the concentration of interleukin-2 (IL-2) was determined by ELISA as previously described [9].

2.6. Assessing the Ability of Dendritic Cells to Induce $T_{\text {Reg }}$ Cells. A single cell suspension of ADLN cells was prepared by physically disaggregating lymph nodes and digesting samples with collagenase IV ( $1 \mathrm{mg} / \mathrm{mL}$, Worthington) and DNase I $\left(0.1 \mathrm{mg} / \mathrm{mL}\right.$, Sigma) for $30 \mathrm{~min}$ at $37^{\circ} \mathrm{C}$. Conventional DCs were enriched from the ADLN cells by removal of CD3+, Thyl.1+ CD19+, GR-1+, and TER-119+ cells using magnetic bead separation as previously described [35]. The remaining cells were then labelled with antibodies specific for CD1lc and MHC class II [9] and MHC class $\mathrm{II}^{\mathrm{hi}} \mathrm{CD} 11 \mathrm{c}^{\text {med }}$ cells sorted by FACS using the FACSAria (BD Biosciences). MHC class $\mathrm{II}^{\text {hi }} \mathrm{CD} 11 \mathrm{c}^{\text {med }}$ cells were incubated with peripheral lymph nodes from naïve DO11.10 (vitamin D-replete) mice (see [9]) at a ratio of $1: 40$ with $1 \mu \mathrm{g} / \mathrm{mL} \mathrm{OVA}_{323-339}$ peptide. DCs were not added to some cultures as controls. Cells were incubated for $62 \mathrm{~h}$ at $37^{\circ} \mathrm{C}$ and $5 \% \mathrm{CO}_{2}$, and then $\mathrm{CD} 3+\mathrm{CD} 4+\mathrm{CD} 25+$ Foxp3 \pm cells were identified by flow cytometry using the FACS LSRII, where at least 5,000 Foxp3+ cells were collected. Data were analyzed using FlowJo software.

2.7. Statistical Analyses. Data were compared using an unpaired two-way Student's $t$-test using Prism 5 statistical analysis program for Mac OS X. Differences were considered significant with a $p$ value $<0.05$. Data are shown throughout as mean \pm SEM.

\section{Results and Discussion}

3.1. Vitamin D Deficiency Promoted Allergic Dermatitis Responses Measured during a Biphasic Ear Swelling Response. We investigated the effects of dietary vitamin $\mathrm{D}$ on allergic dermatitis responses mimicked by inducing a biphasic ear swelling response. We tested adult female offspring of vitamin $\mathrm{D}_{3}$-replete or vitamin $\mathrm{D}_{3}$-deficient $\mathrm{BALB} / \mathrm{c}$ dams, which were maintained on the same diet as their mothers. Serum levels of $25(\mathrm{OH}) \mathrm{D}_{3}$ were $<20 \mathrm{nmol} \cdot \mathrm{L}^{-1}$ for offspring fed the vitamin $\mathrm{D}_{3}$-deficient diet and $>50 \mathrm{nmol} \cdot \mathrm{L}^{-1}$ for offspring fed the vitamin $\mathrm{D}_{3}$-replete diet (Figure 1(a)). These diets did not significantly alter serum calcium $[27,28]$. The contact sensitizer DNFB was then used to initiate a biphasic ear swelling response $[32,33]$. The ears of vitamin $\mathrm{D}_{3}$-deficient or vitamin $\mathrm{D}_{3}$-replete mice were sensitized with $0.05-0.2 \%$ DNFB (in acetone), and ear swelling was recorded over a 3-week period. The ability of dietary vitamin $\mathrm{D}_{3}$ to suppress ear swelling responses depended on the sensitizing dose of DNFB, where responses to $\leq 0.1 \%$ DNFB were suppressed at $144 \mathrm{~h}$ after sensitization, corresponding to the second peak of ear swelling (Figure 1(b)). As expected, the ear swelling response was biphasic, with an initial peak at $3 \mathrm{~h}$ and later peak at $168 \mathrm{~h}$ after DNFB treatment (Figure 1(c)). Previous studies have shown that this first peak represents an early innate influx of neutrophils and inflammatory cells into ear skin, which may depend on histamine release by mast cells [32], while the second peak is an antigen-specific (DNFB) effector response driven by CD $8+\mathrm{T}$ cells expressing interferon- $\gamma$ [33]. Dietary vitamin $\mathrm{D}_{3}$ significantly suppressed (by $61 \%$ ) this second "efferent" ear swelling response, which peaked at $168 \mathrm{~h}$ after DNFB application in vitamin $\mathrm{D}_{3}$-sufficient mice as compared to responses observed in deficient mice (Figure 1(c)).

3.2. Increased Percentages of $T_{\text {Reg }}$ Cells Were Observed in the Skin-Draining Lymph Nodes of Vitamin $D_{3}$-Replete Mice. We have previously published that topically applied $1,25(\mathrm{OH})_{2} \mathrm{D}_{3}$ increased the capacity of $\mathrm{T}_{\text {Reg }}$ cells to suppress contact hypersensitivity responses initiated by DNFB [9]. To examine the effects of dietary vitamin $\mathrm{D}_{3}$ on $\mathrm{T}_{\mathrm{Reg}}$ cells, their percentages in various tissues were measured in naïve female mice prior to sensitization with DNFB. The percentages of $\mathrm{CD} 3+\mathrm{CD} 4+\mathrm{CD} 25+\mathrm{Foxp} 3+\mathrm{T}_{\mathrm{Reg}}$ cells in the skin, SDLN, lung, ADLN, MLN, spleen, and blood were determined by flow cytometry (Figure 2(a), a representative plot for a MLN sample is shown). $\mathrm{CD} 4+\mathrm{T}_{\mathrm{Reg}}$ cell percentages were increased in the SDLN (from $5.0 \pm 0.2$ (vitD-) to $5.7 \pm 0.1$ (vitD+); $14 \%$ increase; $n=6 /$ treatment) and reduced in the ADLN (from $4.8 \pm 0.3$ (vitD-) to $3.3 \pm 0.2$ (vitD+); $31 \%$ reduction; 


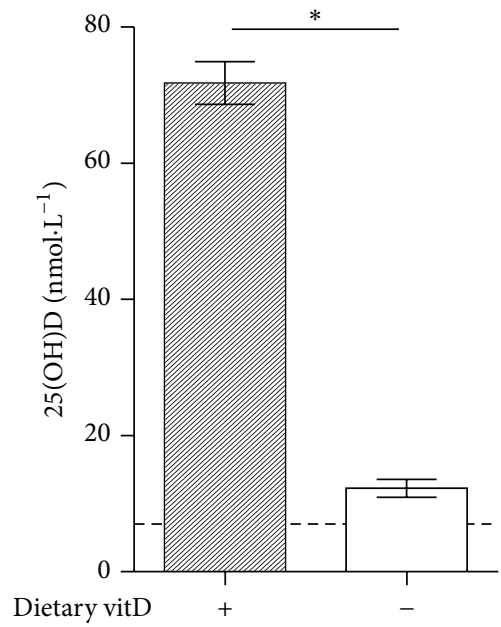

(a)



(b)

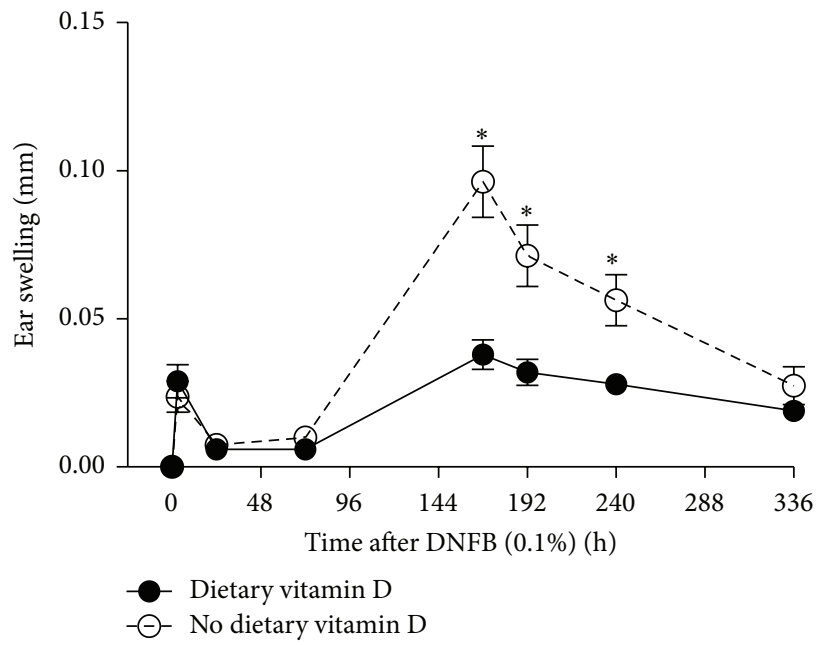

(c)

FIGURE 1: Dietary vitamin D suppressed the biphasic ear swelling response induced by the hapten DNFB. Female offspring born to vitamin $\mathrm{D}_{3}$ - (vitD-) replete $(+)$ or vitamin $\mathrm{D}_{3}$-deficient (-) BALB/c mothers were maintained on vitamin $\mathrm{D}_{3}$-replete or vitamin $\mathrm{D}_{3}$-deficient diets (resp.). (a) Serum $25(\mathrm{OH}) \mathrm{D}_{3}$ levels of female offspring at 8 weeks of age (mean $\pm \mathrm{SEM}$ for $\geq 5$ mice per group). The broken line indicates the level of detection for $25(\mathrm{OH}) \mathrm{D}_{3}(7 \mathrm{pg} / \mathrm{mL})$. In (b), the ear pinnae of mice were sensitized with $0.2,0.1$, or $0.05 \%$ DNFB and the ear swelling response was measured at the second peak of the biphasic response $(144 \mathrm{~h})$. In (c), the ear pinnae of mice were sensitized with $0.1 \%$ DNFB and the resulting biphasic ear swelling response was measured over $305 \mathrm{~h}$. Data are shown as mean \pm SEM in (b) and (c) for 8-12 ear pinnae of 4-6 mice per treatment $\left({ }^{*} p<0.05\right)$. In (b), data are from a single experiment and in (c) they are representative of 2 experiments.

$n=6 /$ treatment) of vitamin $\mathrm{D}_{3}$-replete mice in comparison to vitamin $\mathrm{D}_{3}$-deficient mice, but there was no difference in the percentages of these cells in the skin, lungs, MLN, spleen, or blood (Figure 2(b)). There was also a trend ( $p=0.08$, Student's $t$-test) for increased Foxp3 expression (by $16 \%$ ) on CD3+CD4+CD25+Foxp3+ cells from the SDLN of vitamin $\mathrm{D}_{3}$-replete mice, when geometric mean fluorescence intensity was compared (1053 \pm 43 (vitD+); $910 \pm 63$ (vitD-); $n=6 /$ treatment, data from cells collected in Figure 2(b)). There was no difference in the expression of Foxp3 on CD3+CD4+CD25+Foxp3+ cells from the other tissues (data not shown). With the exception of blood, CD3+CD4+CD25+Foxp3- T "effector" cell ( $\left.\mathrm{T}_{\mathrm{Eff}}\right)$ (Figure $2(\mathrm{c})$ ) percentages were unaffected by vitamin $\mathrm{D}_{3}$ deficiency. In male mice, CD3+CD4+CD25+Foxp3+ $\mathrm{T}_{\mathrm{Reg}}$ cell percentages were affected in a similar way by dietary vitamin $\mathrm{D}_{3}$ as those observed in female mice and were increased in the SDLN (by 21\%) (from $4.1 \pm 0.3$ (vitD-) to $5.0 \pm$ 0.2 (vitD+); $n=6 /$ treatment) and reduced in ADLN (by 23\%) (from $4.3 \pm 0.3$ (vitD-) to $3.3 \pm 0.1$ (vitD+); $n=$ $6 /$ treatment). There was also an increase (42\%) in the percentage of CD3+CD4+CD25+Foxp3- $\mathrm{T}_{\text {Eff }}$ cells in the SDLN of male mice fed a vitamin $\mathrm{D}_{3}$-containing diet (from to $0.31 \pm$ 0.04 (vitD-) to $0.44 \pm 0.04$ (vitD+); $42 \%$ increase; $n=$ $6 /$ treatment).

The number of cells isolated from the SDLN was altered by vitamin $\mathrm{D}_{3}$ supplementation of female mice. Significantly fewer SDLN cells $\left(2.8 \pm 0.4 \times 10^{7} /\right.$ mouse (vitD-); 

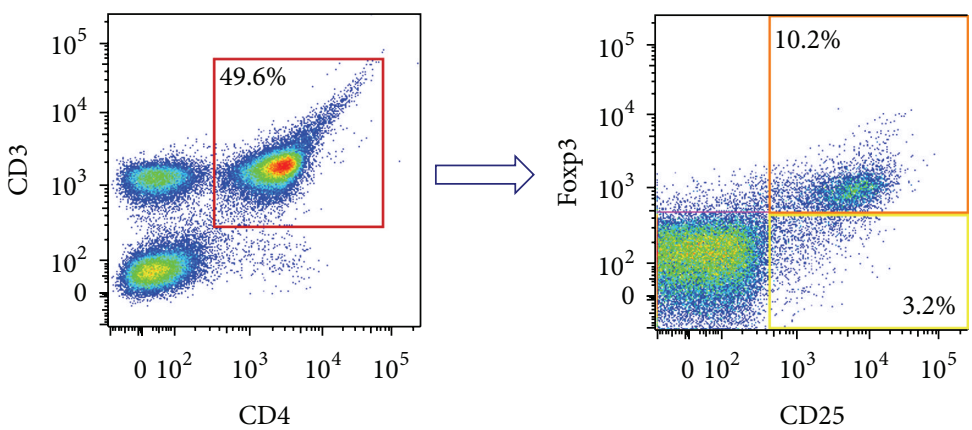

(a)
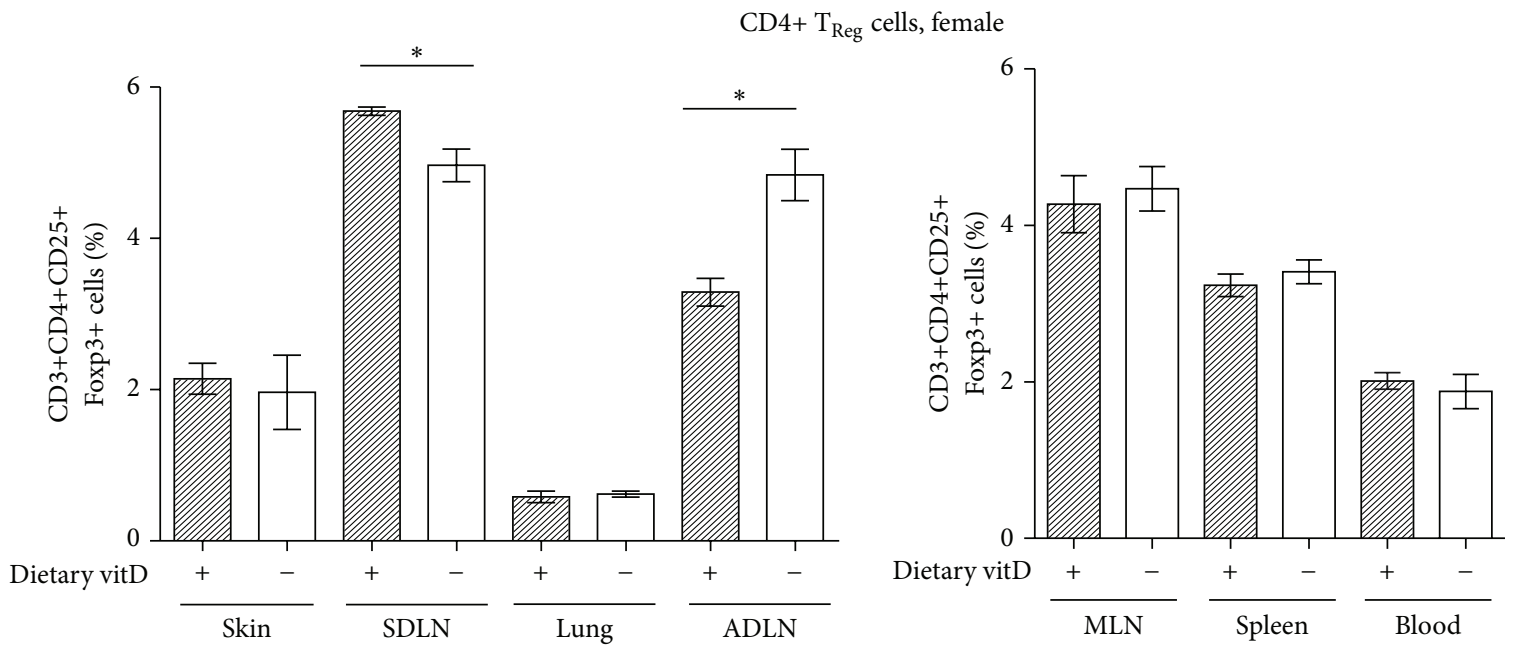

(b)
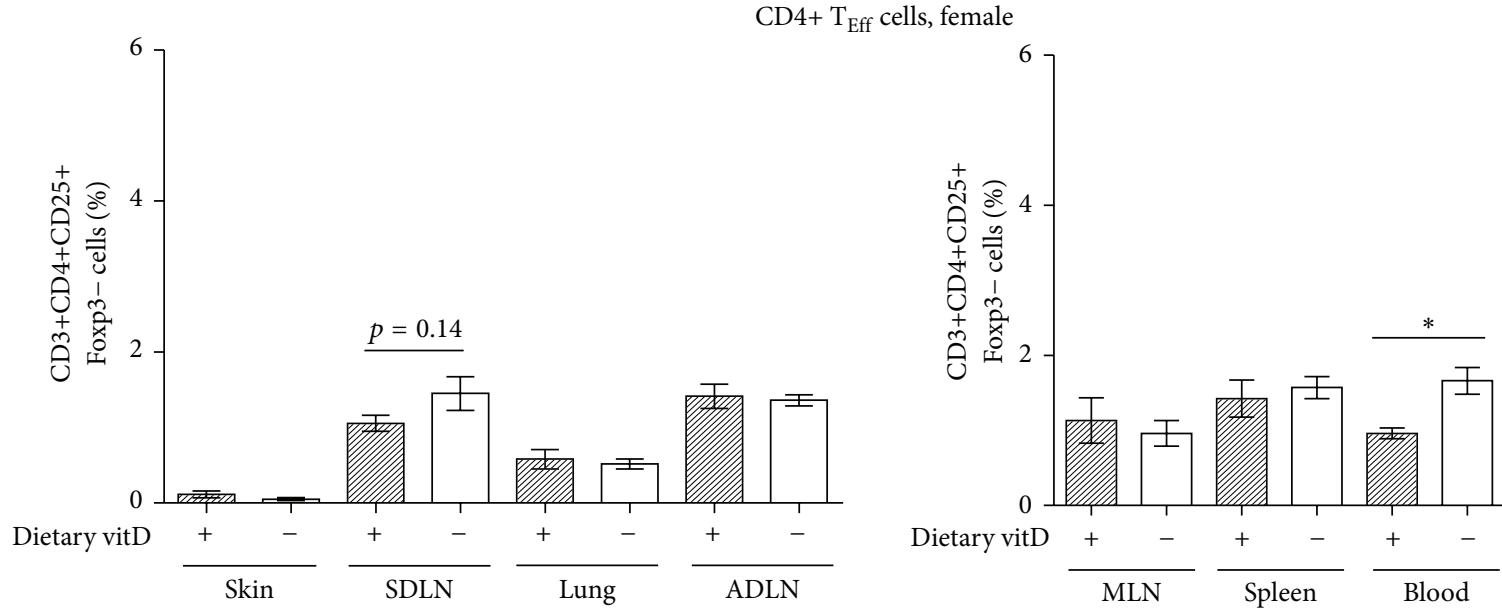

(c)

FIgURE 2: Dietary vitamin $\mathrm{D}_{3}$ increased the percentage of Foxp3 $+\mathrm{T}_{\mathrm{Reg}}$ cells in the SDLN. Female offspring born to vitamin $\mathrm{D}_{3}$ - (vitD-) replete (+) or vitamin $\mathrm{D}_{3}$-deficient (-) BALB/c mothers were maintained on the vitamin $\mathrm{D}_{3}$-replete or vitamin $\mathrm{D}_{3}$-deficient diets (resp.). (a) The FACS gating strategy for determining the percentage of CD3+CD4+CD25+Foxp3+ $\left(\mathrm{T}_{\mathrm{Reg}}\right.$ cells, orange $)$ or CD3+CD4+CD25+Foxp3$\left(\mathrm{T}_{\mathrm{Eff}}\right.$ cells, yellow) cells in skin, SDLN, lung, ADLN, MLN, spleen, and blood. Representative plots from a MLN sample are shown. For all tissues, a gate was used to exclude red blood cells using forward and side scattering properties of cells prior to selection of the various T cell populations. (b) and (c) The percentage of $\mathrm{T}_{\text {Reg }}$ cells and $\mathrm{T}_{\mathrm{Eff}}$ cells (resp.) in various tissues. Data are shown as mean \pm SEM for 6 mice/treatment with results combined from two experiments; ${ }^{*} p<0.05$. 


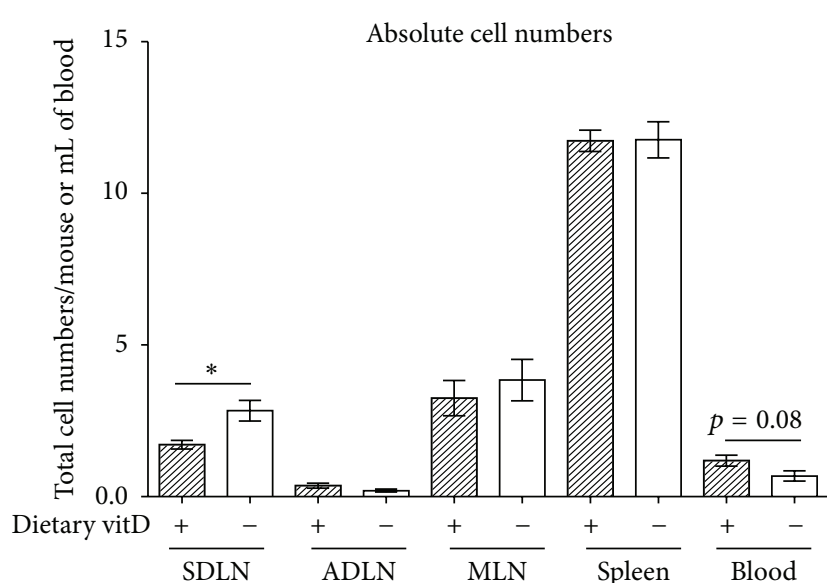

(a)

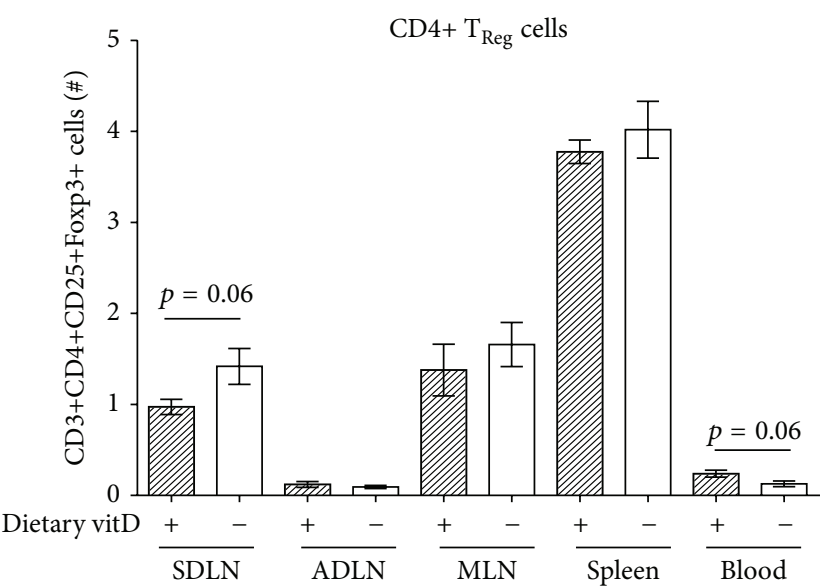

(b)

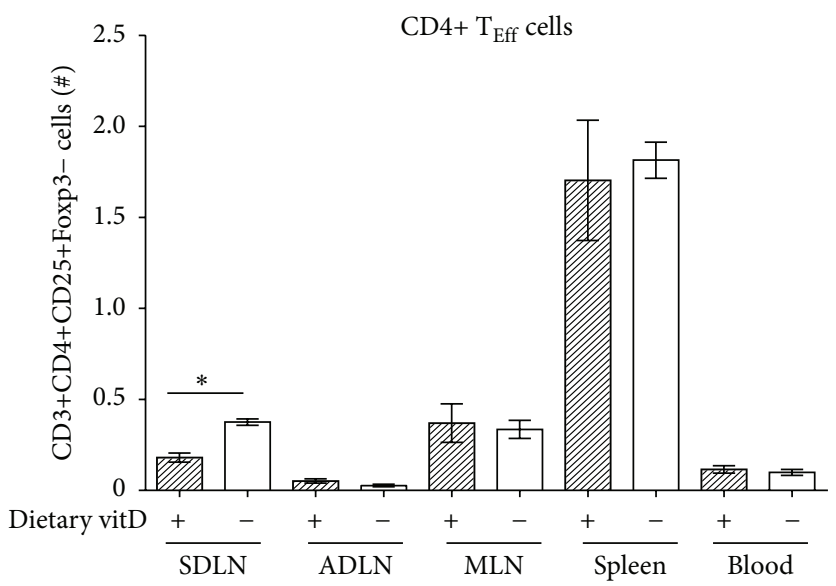

(c)

FIGURE 3: Dietary vitamin $\mathrm{D}_{3}$ reduced the absolute number of cells in the SDLN. Female offspring born to vitamin $\mathrm{D}_{3}$ - (vitD-) replete $(+)$ or vitamin $\mathrm{D}_{3}$-deficient $(-) \mathrm{BALB} / \mathrm{c}$ mothers were maintained on the vitamin $\mathrm{D}_{3}$-replete or vitamin $\mathrm{D}_{3}$-deficient diets (resp.). In (a), the number of cells $\left(\times 10^{7}\right)$ /mouse or $\mathrm{mL}$ of blood isolated from the SDLN, ADLN, MLN, spleen, or blood is shown. The numbers of $\mathrm{CD} 3+\mathrm{CD} 4+\mathrm{CD} 25+\mathrm{Foxp} 3+\left(\mathrm{T}_{\text {Reg }}\right.$ cells $)$ or $\mathrm{CD} 3+\mathrm{CD} 4+\mathrm{CD} 25+\mathrm{Foxp} 3-\left(\mathrm{T}_{\mathrm{Eff}}\right.$ cells $)$ cells in these tissues were calculated using the percentages depicted in Figure 2. In (b) and (c), the number of CD4+ $\mathrm{T}_{\mathrm{Reg}}$ and $\mathrm{T}_{\mathrm{Eff}}$ cells $\left(\times 10^{6}\right) /$ mouse or $\mathrm{mL}$ of blood is shown. Data are shown as mean \pm SEM for 6 mice/treatment with results combined from two experiments; ${ }^{*} p<0.05$.

$1.7 \pm 0.1 \times 10^{7} /$ mouse $($ vitD+); $39 \%$ reduction; $n=$ 6/treatment) were isolated from vitamin $\mathrm{D}_{3}$-supplemented mice (Figure 3(a)). These effects were in the opposite direction to those of dietary vitamin $\mathrm{D}_{3}$ on $\mathrm{T}_{\mathrm{Reg}}$ cell percentages in the SDLN. There was no difference in the numbers of cells isolated from other tissues (Figure 3(a); data not shown for skin and lung). There was a trend for fewer CD4+ $\mathrm{T}_{\mathrm{Reg}}$ cell numbers in the SDLN $\left(1.5 \pm 0.2 \times 10^{6} /\right.$ mouse (vitD-); $0.9 \pm$ $0.1 \times 10^{6} /$ mouse $($ vitD +$\left.)\right) ; 40 \%$ reduction; $n=6 /$ treatment) of vitamin $\mathrm{D}_{3}$-supplemented mice in comparison to vitamin $\mathrm{D}_{3}$-deficient mice (Figure 3(b)). Similarly, numbers of $\mathrm{CD} 3+\mathrm{CD} 4+\mathrm{CD} 25+$ Foxp3 $-\mathrm{T}_{\mathrm{Eff}}$ cells were significantly reduced in the SDLN of mice fed a vitamin $\mathrm{D}_{3}$-supplemented $\operatorname{diet}\left(3.8 \pm 0.2 \times 10^{5} /\right.$ mouse (vitD-); $1.8 \pm 0.2 \times 10^{5} /$ mouse $($ vitD +$) ; 53 \%$ reduction; $n=6 /$ treatment) (Figure $3(\mathrm{c})$ ). There was no effect of dietary vitamin $\mathrm{D}_{3}$ on the total cell numbers or numbers of $\mathrm{T}_{\text {Reg }}$ or $\mathrm{T}_{\text {Eff }}$ cells identified in the SDLN, ADLN, or blood of male mice (data not shown). These data suggest that while the proportions of CD4+ $\mathrm{T}_{\text {Reg }}$ cells increased in the SDLN with dietary vitamin $\mathrm{D}_{3}$, this significant increase did not persist when cell numbers were considered, as significantly fewer SDLN cells were isolated from mice fed a diet containing vitamin $\mathrm{D}_{3}$.

3.3. The Suppressive Activity of $T_{\text {Reg }}$ Cells Was Enhanced by Dietary Vitamin $D_{3}$ in Most Immune Tissues but Not the Airway-Draining Lymph Nodes. An in vitro assay was used to test if dietary vitamin $\mathrm{D}_{3}$ altered the suppressive function of $\mathrm{T}_{\text {Reg }}$ cells in comparison to those from vitamin $\mathrm{D}_{3}$-deficient mice. Purified CD4+CD25+(Foxp3+) cells were cocultured with responder lymph node cells from DO11.10 mice and $\mathrm{OVA}_{323-339}$ peptide for $92 \mathrm{~h}$. Responder CD4+ T cells expressing the OVA ${ }_{323-339}$ TCR proliferate and produce cytokines like IL-2 in response to presentation of the $\mathrm{OVA}_{323-339}$ peptide by antigen-presenting cells. We assessed IL-2 levels as a measure of the proliferative capacity of responder cells, where 
cocultured $\mathrm{T}_{\text {Reg }}$ cells significantly suppressed supernatant levels of IL-2 in a dose-dependent manner (Figure 4). $\mathrm{T}_{\mathrm{Reg}}$ cells produce very low levels of IL-2 when stimulated in vitro. These levels are up to 10 times less than $\mathrm{CD} 4+\mathrm{T}_{\mathrm{Eff}}$ responder cells [12]. $\mathrm{T}_{\mathrm{Reg}}$ cells therefore do not significantly contribute towards the pool of IL-2 in coculture assays. CD4+CD25+(Foxp3+) cells from the SDLN (Figure 4(a)), MLN (Figure 4(c)), spleen (Figure 4(d)), and blood (Figure $4(\mathrm{e})$ ) of vitamin $\mathrm{D}_{3}$-replete mice had increased capacity to suppress IL-2 production by cocultured responder cells. There was no significant difference in suppressive function observed for CD4+CD25+(Foxp3+) cells from the ADLN (Figure $4(\mathrm{~b})$ ) of vitamin $\mathrm{D}_{3}$-replete or vitamin $\mathrm{D}_{3}$-deficient mice. The results reported in Figure 4 were for suppressive activities of CD4+CD25+(Foxp3+) cells from female mice; however, similar results were obtained for cells from male mice (data not shown). We were not technically able to assess the suppressive activity of $\mathrm{T}_{\text {Reg }}$ cells in the skin or lungs as their numbers were too infrequent for efficient isolation. These data suggest that dietary vitamin $\mathrm{D}_{3}$ is required for the optimal activity of $\mathrm{T}_{\mathrm{Reg}}$ cells at various immune sites throughout the body, with the exception of the ADLN.

\subsection{Vitamin $D_{3}$ Did Not Induce $T_{\text {Reg }}$ Cells in the Periphery.} Surface expression of neuropilin can be used to identify naturally occurring $\mathrm{T}_{\mathrm{Reg}}$ cells [36]. We examined the expression of neuropilin on $\mathrm{T}_{\mathrm{Reg}}$ cells from the skin, SDLN, lungs, or ADLN of vitamin $D_{3}$-replete or vitamin $D_{3}$-deficient mice and observed no difference in the expression of this molecule (Figure 5(a)). These results suggest that dietary vitamin $\mathrm{D}_{3}$ did not favour the induction of new $\mathrm{T}_{\text {Reg }}$ cells in the SDLN. The observed reduction in the percentage of $T_{\text {Reg }}$ cells in the ADLN of mice fed a vitamin $\mathrm{D}_{3}$-containing diet was a surprising result. A lack of difference in neuropilin expression on $\mathrm{T}_{\mathrm{Reg}}$ cell from the ADLN of vitamin $\mathrm{D}_{3}$-replete and vitamin $D_{3}$-deficient mice suggested that dietary vitamin $D_{3}$ did not prevent the induction of new $\mathrm{T}_{\text {Reg }}$ cells (Figure 5(a)). However, to confirm this observation, we then tested whether there was a functional difference between DCs from vitamin $\mathrm{D}_{3}$-deficient and vitamin $\mathrm{D}_{3}$-replete mice, as DCs are required for the induction of new $\mathrm{T}_{\mathrm{Reg}}$ cells in the periphery [37]. Conventional MHC class $\mathrm{II}^{\mathrm{hi}} \mathrm{CD} 11 \mathrm{c}^{\text {med }} \mathrm{DCs}$ were sorted (Figure 5(b)) from the ADLN of vitamin $\mathrm{D}_{3}$-replete and vitamin $\mathrm{D}_{3}$-deficient mice and cocultured with lymph node cells from naive DO11.10 mice and OVA peptide. The percentage of CD4+CD25+Foxp3 \pm cells was determined after $62 \mathrm{~h}$ of coculture (Figure 5(c)). CD4+CD25+Foxp3- $\mathrm{T}_{\mathrm{Eff}}$ cell and $\mathrm{CD} 4+\mathrm{CD} 25+\mathrm{Foxp} 3+\mathrm{T}_{\mathrm{Reg}}$ cell percentages were increased ( $>2$-fold) by the presence of DCs in the cocultures (Figures 5 (c) and 5(d)). However, there was no effect of dietary vitamin $\mathrm{D}_{3}$ on the ability of ADLN DCs to regulate $\mathrm{T}_{\text {Reg }}$ cell percentages (Figure 5(d)). These results suggest that dietary vitamin $\mathrm{D}_{3}$ did not impair the induction of new $\mathrm{T}_{\mathrm{Reg}}$ cells in the ADLN.

3.5. Dietary Vitamin $D_{3}$ Did Not Affect the Expression of CCR4 or CCR10 on $T_{\text {Reg }}$ Cells in the SDLN or ADLN. Dietary vitamin $\mathrm{D}_{3}$ could induce the migration of $\mathrm{T}_{\text {Reg }}$ cells to augment the percentages of these cells in the SDLN, facilitated by the expression of chemokine receptors. There was no difference in the expression of the skin-homing receptors CCR4 or CCR10 on $\mathrm{T}_{\text {Reg }}$ cells in the skin, SDLN, lungs, or ADLN of vitamin D-replete or vitamin D-deficient mice (Figures 6(a) and 6(b)). Significant levels of CCR4 (Figure 6(a)) were detected on $\mathrm{T}_{\text {Reg }}$ cells in skin and SDLN with less expression on cells from the lung and ADLN, while similar levels of CCR10 (Figure 6(b)) were identified on $\mathrm{T}_{\text {Reg }}$ cells from these tissues. While dietary vitamin $\mathrm{D}_{3}$ promoted $\mathrm{T}_{\text {Reg }}$ cell accumulation in the SDLN, there was no difference in the expression of CCR4 and CCR10 skin-homing receptors once cells entered the SDLN.

3.6. Dietary Vitamin $D_{3}$ May Promote Dermal Tolerance to Reduce Skin Inflammation. Our findings of the immunosuppressive effects of dietary vitamin $\mathrm{D}_{3}$ in controlling DNFBinduced skin inflammation reiterate emerging data from clinical trials, which suggest that vitamin $\mathrm{D}_{3}$ supplementation reduces symptoms of allergic dermatitis [26]. Similar suppressive effects of dietary vitamin $\mathrm{D}_{3}$ have been observed in other animal models that used haptens to induce skin inflammation [38]. In other studies, hypocalcaemia induced by vitamin $\mathrm{D}_{3}$ deficiency may have impaired hapten-induced ear swelling responses [39]. The vitamin $\mathrm{D}_{3}$-containing diets used in our studies and those of others [38] were enriched with calcium to prevent hypocalcemia [27, 28]. While clinical trials suggest that maintaining optimal serum levels of $25(\mathrm{OH}) \mathrm{D}$ through dietary vitamin $\mathrm{D}_{3}$ supplementation (or safe sun exposure) reduces symptoms of atopic dermatitis [26], we are still uncertain of the optimal levels of $25(\mathrm{OH}) \mathrm{D}$ needed to limit atopic dermatitis. It is also important to note that some studies have observed no significant effect of vitamin $\mathrm{D}_{3}$ supplementation [40], with suggestions that genetic or other population-based factors (e.g., initial circulating $25(\mathrm{OH}) \mathrm{D}$ levels) or the supplementation regimen (e.g., dose, schedule of treatment, and type of vitamin D) may have limited the efficacy of the vitamin $\mathrm{D}$ treatment.

3.7. Dietary Vitamin $D_{3}$ Increased the Percentages and Activity of $T_{\text {Reg }}$ Cells in the SDLN. We observed a greater suppressive activity of $\mathrm{CD} 4+\mathrm{CD} 25+(\mathrm{Foxp} 3+)$ cells isolated from the SDLN, MLN, spleen, and blood of mice fed the vitamin D-containing diet, suggesting a systemic effect of dietary vitamin $\mathrm{D}$ on $\mathrm{T}_{\text {Reg }}$ cell activity. It is important to note that we examined $\mathrm{T}_{\mathrm{Reg}}$ cell numbers and function prior to sensitization with DNFB, and so these findings are independent of skin inflammation induced by the irritant. These observations were accompanied by a lack of effect of dietary vitamin $\mathrm{D}$ on the suppressive activity of cells from the ADLN. This curious observation is difficult to explain but may represent a site from which $\mathrm{T}_{\text {Reg }}$ cells actively migrate (to the SDLN). We did not observe increased expression of skintropic chemokine receptors CCR4 or CCR10 on $\mathrm{T}_{\mathrm{Reg}}$ cells from any of the tested sites (skin, SDLN, lung, and ADLN) of vitamin $\mathrm{D}_{3}$-fed mice, but it may be that these molecules are upregulated during transition (in blood) between locations, which could be a focus of future studies. Crosstalk between the immune reactions initiated in the skin and 


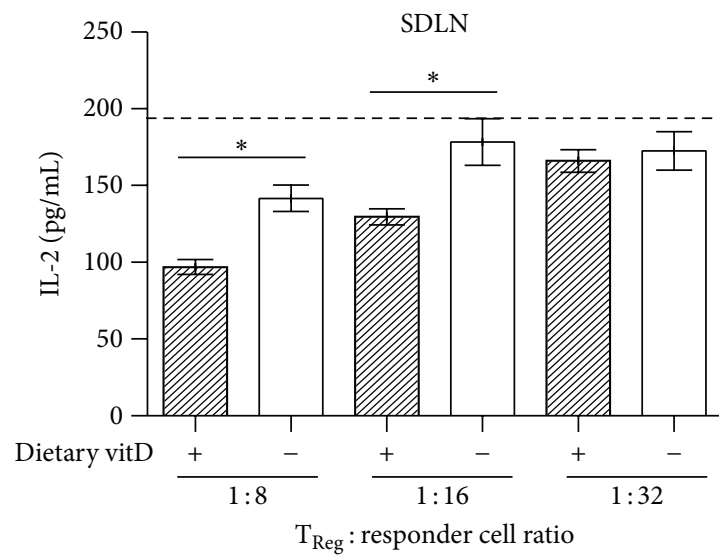

(a)

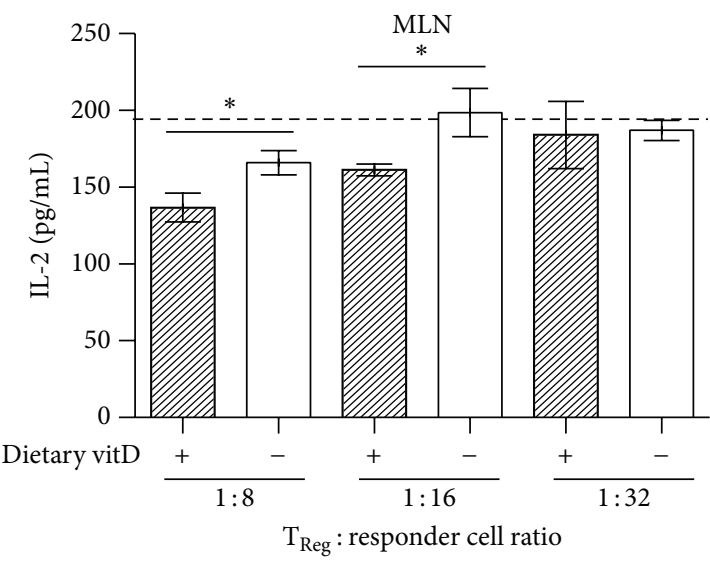

(c)

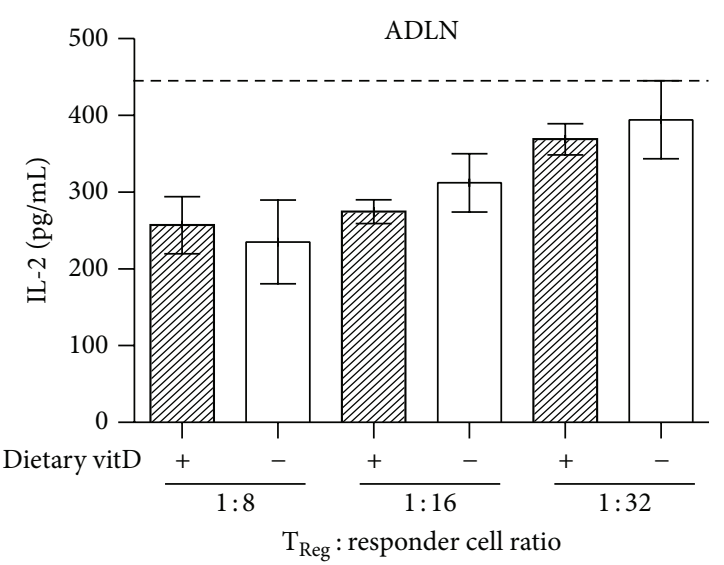

(b)

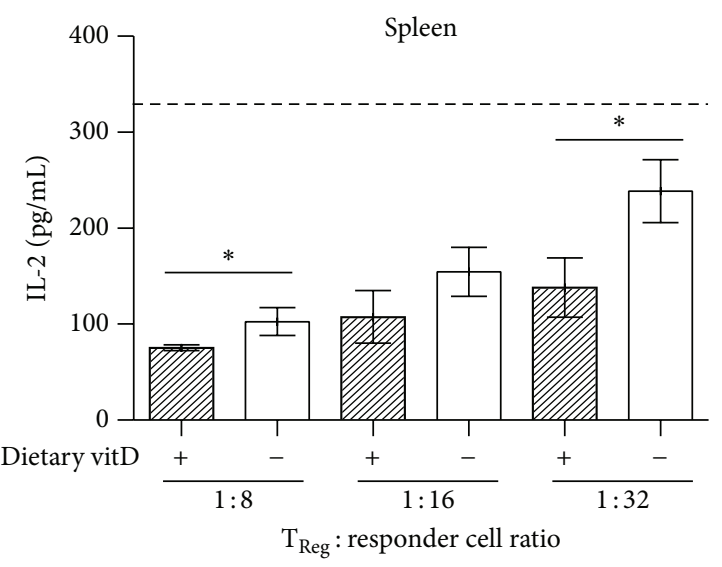

(d)

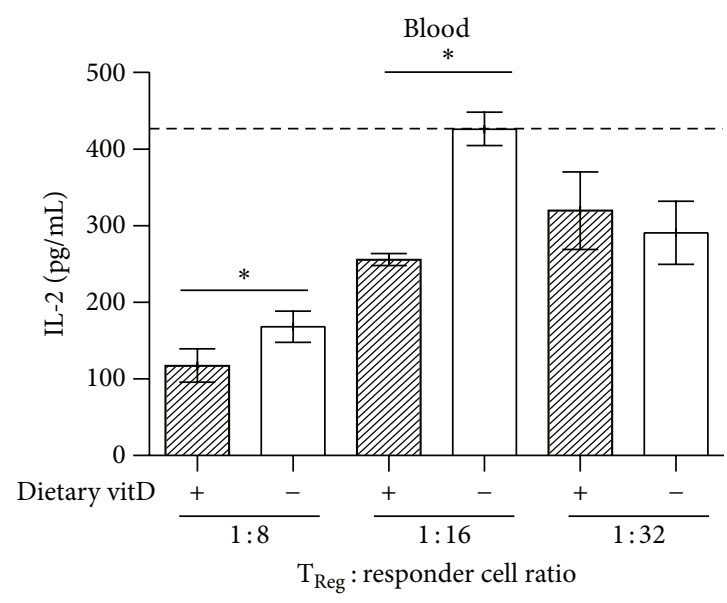

(e)

Figure 4: Dietary vitamin $\mathrm{D}$ enhanced the activity of Foxp3 $+\mathrm{T}_{\mathrm{Reg}}$ cells at multiple immune sites. Female offspring born to vitamin $\mathrm{D}_{3}$ (vitD-) replete $(+)$ or vitamin $\mathrm{D}_{3}$-deficient (-) DO11.10 mothers were maintained on vitamin $\mathrm{D}$-replete or vitamin $\mathrm{D}$-deficient diets (resp.) until 8 weeks of age. CD4+CD25+(Foxp3+) cells were purified from (a) SDLN, (b) ADLN, (c) MLN, (d) spleens, or (e) blood of mice and cocultured with lymph node responder cells from DO11.10 mice at ratios of $1: 8,1: 16$, or 1:32 and OVA peptide. IL-2 levels in the coculture supernatants were measured after $96 \mathrm{~h}$. The broken lines indicate the levels of IL-2 measured in supernatant of responder cells cultured with OVA peptide alone. Data are shown as mean \pm SEM for 6 wells/treatment, representative of two experiments; ${ }^{*} p<0.05$. 


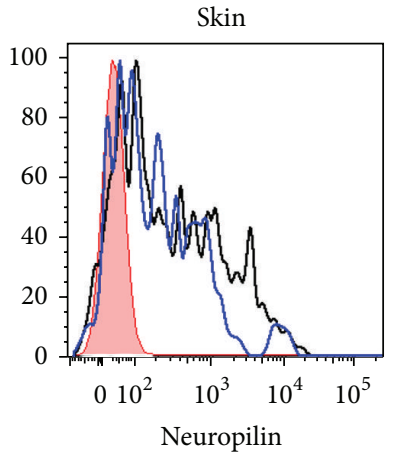

_ Unstained

- VitD+

- VitD
SDLN

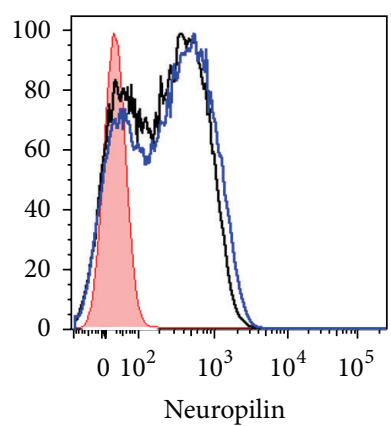

— Unstained

- VitD+

VitD-

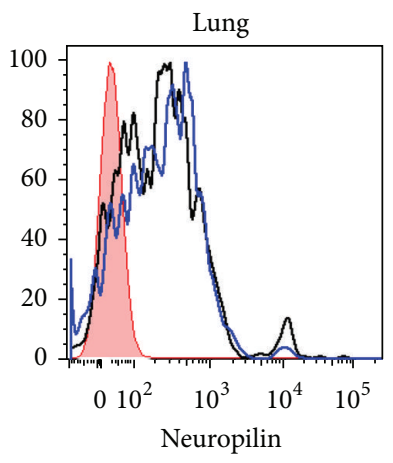

- Unstained

- VitD+
ADLN

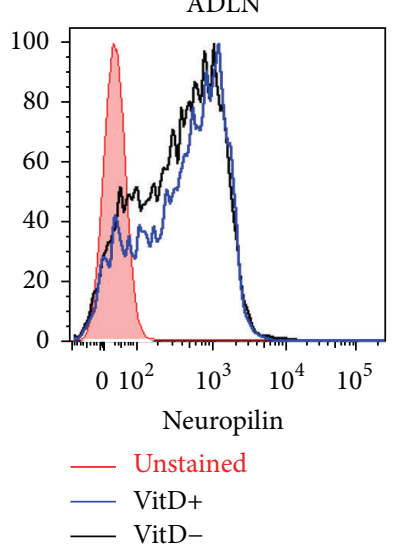

(a)

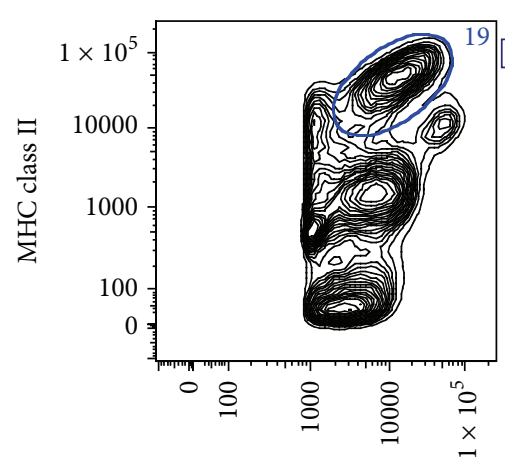

CD11c

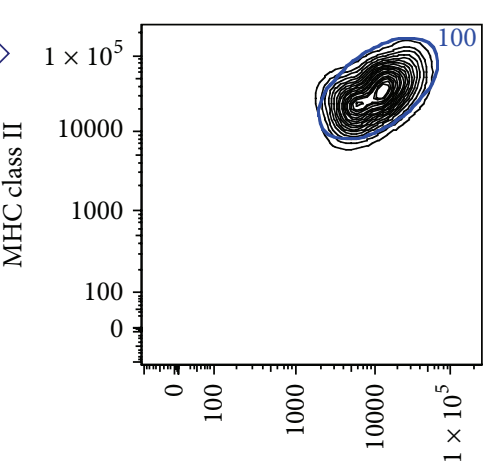

CD11c

(b)
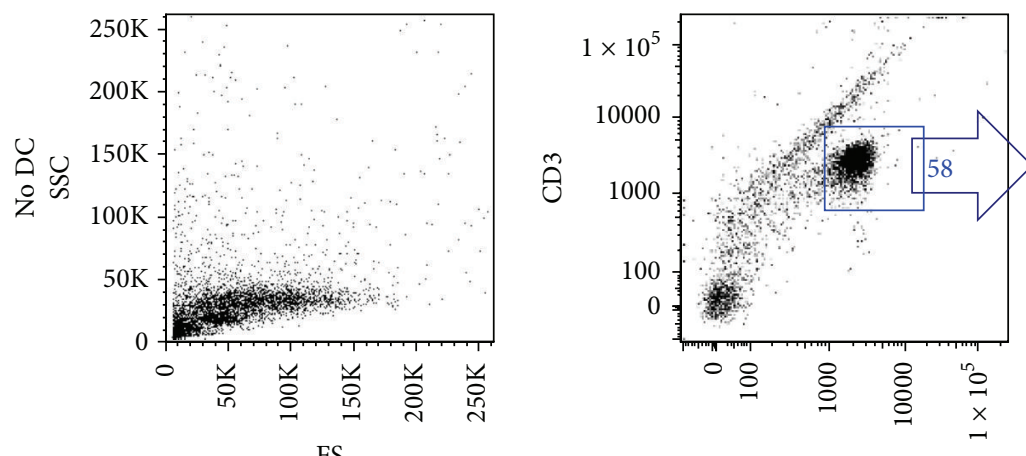

CD4
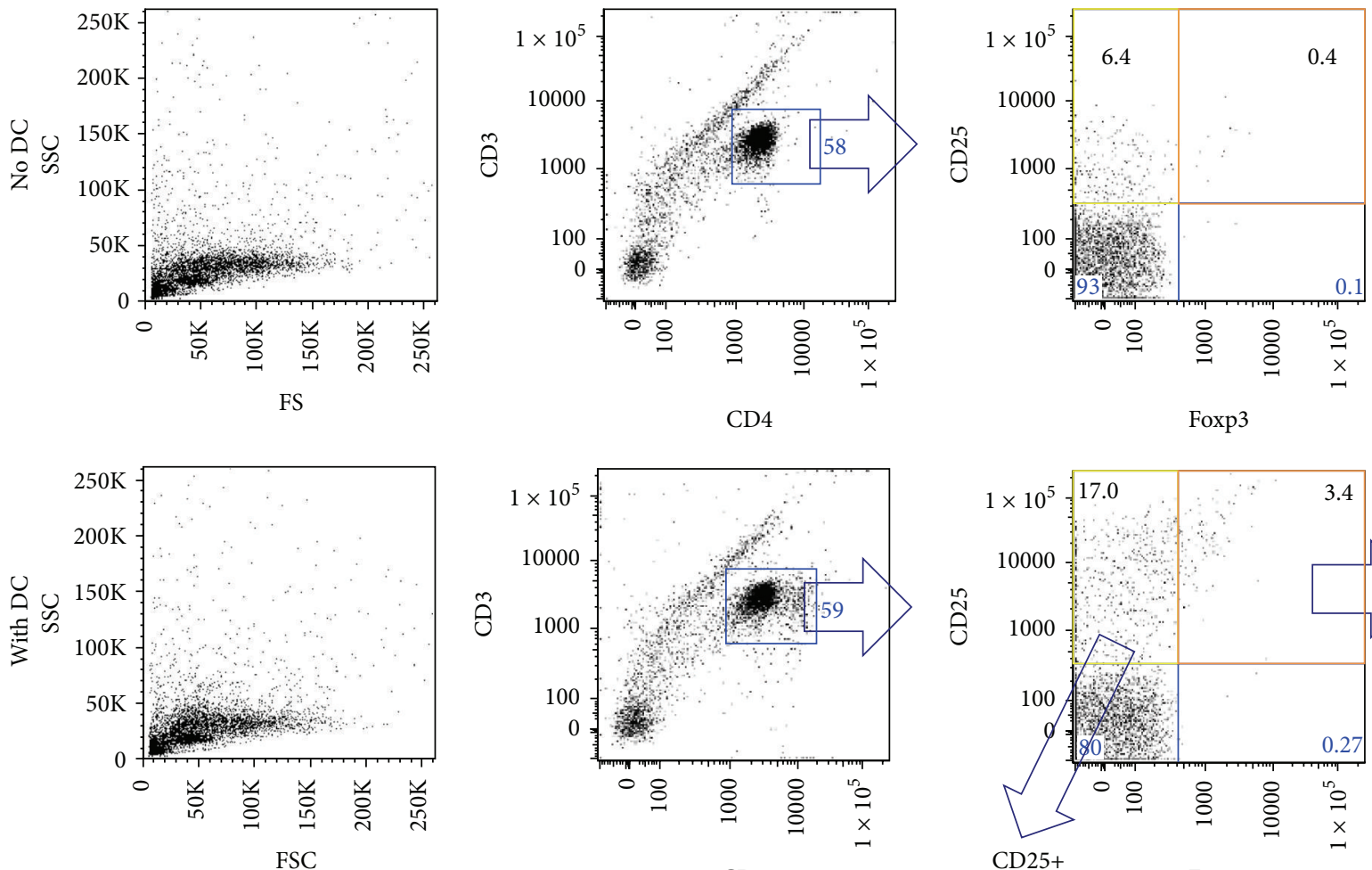

CD4

(c)

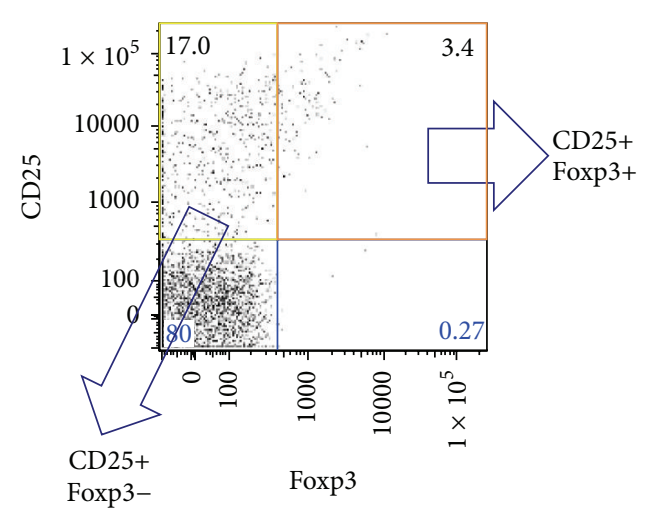

FIgURE 5: Continued. 


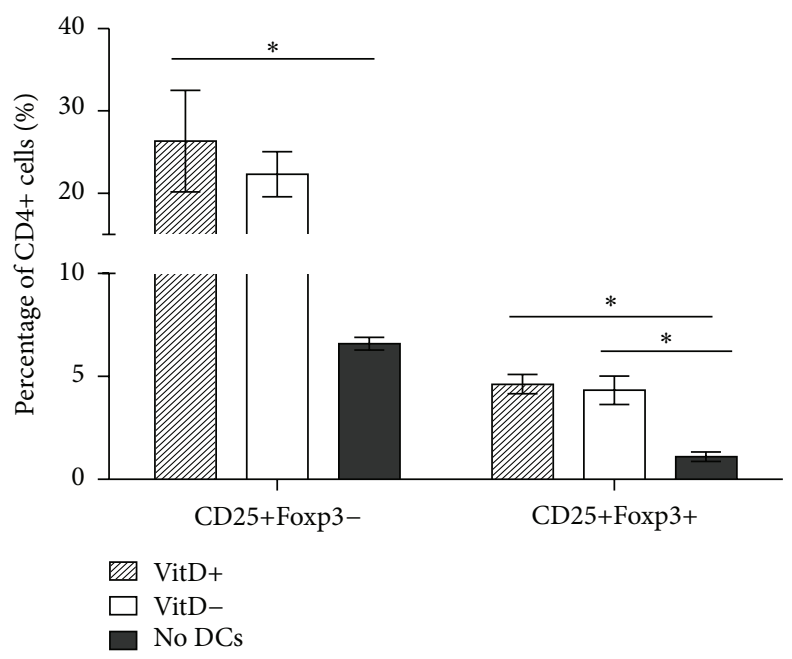

(d)

Figure 5: Dietary vitamin $\mathrm{D}_{3}$ did not modify neuropilin expression on Foxp3+ $\mathrm{T}_{\mathrm{Reg}}$ cells from the skin, SDLN, lung, or ADLN or alter the capacity of DCs from the ADLN to induce new Foxp3 $+\mathrm{T}_{\text {Reg }}$ cells. Female offspring born to vitamin $\mathrm{D}_{3}$-replete or vitamin $\mathrm{D}_{3}$-deficient $\mathrm{BALB} / \mathrm{c}$ mothers were maintained on the vitamin $\mathrm{D}_{3}$-replete (vitD+) or vitamin $\mathrm{D}_{3}$-deficient (vitD-) diets (resp.) until 8 weeks of age. In (a), the expression of neuropilin in the skin, SDLN, lungs, and ADLN is shown, with cells from vitamin $\mathrm{D}_{3}$-replete and vitamin $\mathrm{D}_{3}$-deficient mice shown in blue and black, respectively (unstained = red shaded). Data are representative of two experiments. In (b), MHC class II ${ }^{\text {hi }} \mathrm{CD} 11 \mathrm{c}^{\mathrm{med}}$ cells from the ADLN were sorted with the prepurity (left) and postpurity (right) shown, as determined by flow cytometry. These cells were cocultured with lymph node cells from OVA-TCR transgenic mice (DO11.10 mice) at a ratio of 0:1 (no DC) or 1:40 (with DC) for 62 h with OVA peptide. (c) The gating strategy for determining the percentage of CD25+Foxp3- and CD25+Foxp3+ cells after $62 \mathrm{~h}$ of coculture. In (d), the percentages of CD25+Foxp3- and CD25+Foxp3+ cells of CD4+CD3+ cells are shown as mean \pm SEM for 3 wells/treatment. ${ }^{*} p<0.05$.

airways is illustrated by the "atopic march" concept, where allergic responses in the skin affect immunity in the airways. Indeed, hapten-induced skin inflammation can worsen signs of allergic airway disease in mice [41]. We suggest that dietary vitamin $\mathrm{D}_{3}$ may prevent the "atopic march" by promoting $\mathrm{T}_{\text {Reg }}$ cell accumulation and activity in the SDLNs. The lack of difference in neuropilin levels suggests that vitamin $\mathrm{D}_{3}$ may increase SDLN $\mathrm{T}_{\mathrm{Reg}}$ cell accumulation through migration.

3.8. Inconsistencies between These Observations and Other Published Data. Urry et al. (2012) observed a positive correlation between circulating $25(\mathrm{OH}) \mathrm{D}$ and the percentages of $\mathrm{T}_{\text {Reg }}$ cells in the airways (lavage fluid) of children with severe asthma [42]. We did not see any difference in the percentages of $\mathrm{T}_{\text {Reg }}$ cells in the lungs of mice fed a vitamin $\mathrm{D}_{3}$-replete or vitamin $\mathrm{D}_{3}$-deficient diet and did not assess the percentages of these cells in the trachea or bronchoalveolar lavage fluid. Furthermore, reduced percentages of $\mathrm{T}_{\text {Reg }}$ cells were observed in the ADLN of mice fed a vitamin $\mathrm{D}_{3}$-replete diet. In addition, it is possible that, upon respiratory stimulation with allergen, $\mathrm{T}_{\mathrm{Reg}}$ cell percentages could increase in the lungs of vitamin $\mathrm{D}_{3}$-replete mice. In other studies, Mann et al. (2015) found that more CD4+ cells stimulated with $1,25(\mathrm{OH})_{2} \mathrm{D}(100 \mathrm{nM})$ in vitro expressed neuropilin compared to control cells [43]. It is therefore possible that new $\mathrm{T}_{\mathrm{Reg}}$ cells may be generated under conditions of highly concentrated $1,25(\mathrm{OH})_{2} \mathrm{D}_{3}$.

3.9. Modelling Skin Inflammation. We induced a biphasic cutaneous skin reaction using the contact sensitizer DNFB to examine the effects of dietary vitamin $\mathrm{D}_{3}$ on skin inflammation. A humanized mouse model would have been an interesting alternative means of comparing these treatments through xenotransplantation of human skin [44] or bioengineered human skin equivalents [45] onto immunodeficient mice. These models can induce some (but not all) clinical manifestations of atopic dermatitis, particularly acute lesions [45]. While such models would improve our understanding of the effects of dietary vitamin $\mathrm{D}_{3}$ in humanized settings, we were more interested in the capacity of dietary vitamin $\mathrm{D}_{3}$ to modulate $\mathrm{T}_{\text {Reg }}$ cell proportions and function in certain tissues (e.g., skin or lungs) prior to the onset of inflammation.

\section{Conclusion}

Our studies suggest that dietary vitamin $\mathrm{D}_{3}$ increased the percentages and suppressive function of $\mathrm{T}_{\text {Reg }}$ cells in the SDLN and that these cells are poised to suppress dermal inflammation. These studies support the notion that maintaining adequate serum $25(\mathrm{OH}) \mathrm{D}$ through dietary vitamin $\mathrm{D}_{3}$ supplementation or safe sun exposure is important to reduce the severity of allergic dermatitis and other inflammatory skin conditions.

\section{Abbreviations}

$1,25(\mathrm{OH})_{2} \mathrm{D}_{3}: 1,25$-Dihydroxyvitamin $\mathrm{D}_{3}$ $25(\mathrm{OH}) \mathrm{D}_{3}: \quad 25$-Hydroxyvitamin $\mathrm{D}_{3}$ ADLN: $\quad$ Airway-draining lymph nodes

DNFB: 2,4-Dinitrofluorobenzene 


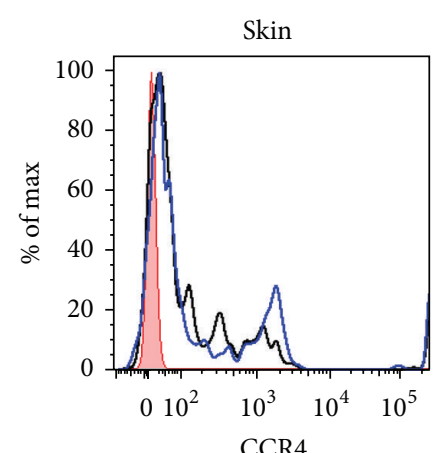

Unstained
— VitD+
- VitD-
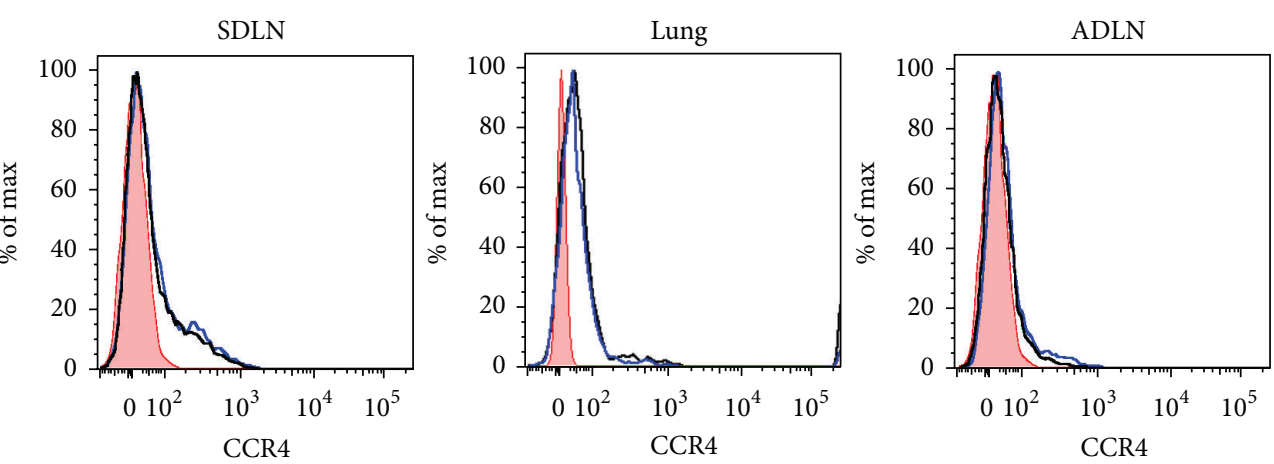

(a)
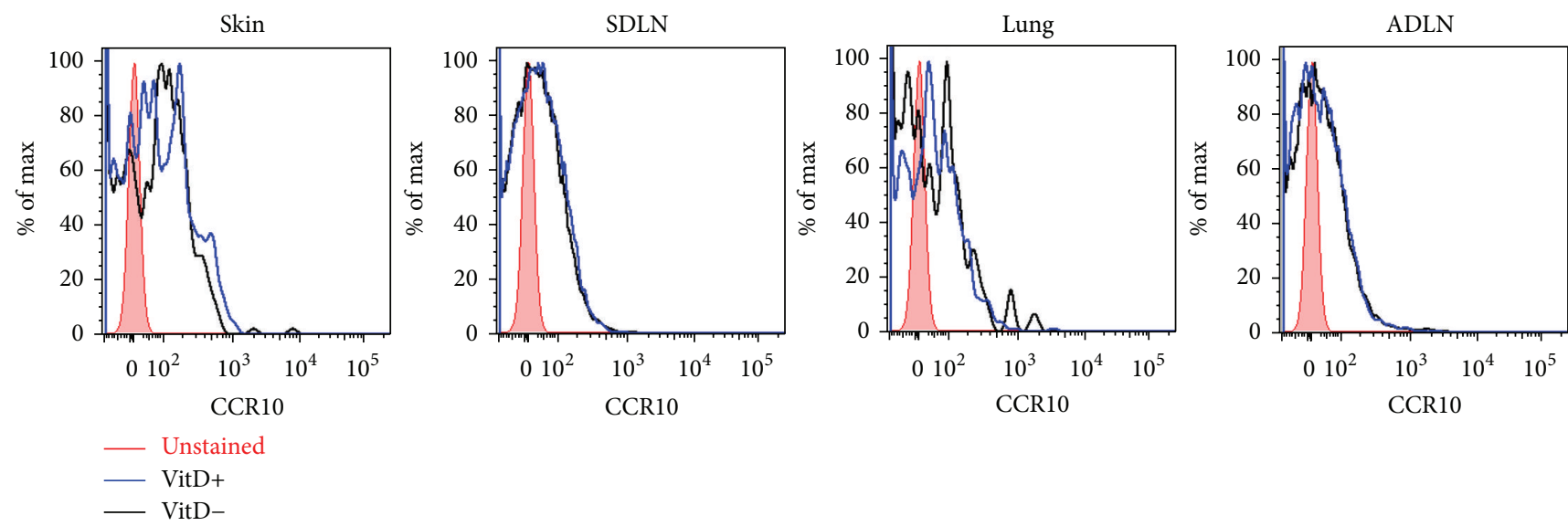

(b)

FIgURE 6: Dietary vitamin $\mathrm{D}_{3}$ did not modify CCR4 or CCR10 expression on Foxp3 $+\mathrm{T}_{\mathrm{Reg}}$ cells from the skin, SDLN, lung, or ADLN. Female offspring born to vitamin $\mathrm{D}_{3}$-replete or vitamin $\mathrm{D}_{3}$-deficient $\mathrm{BALB} / \mathrm{c}$ mothers were maintained on the vitamin $\mathrm{D}_{3}$-replete $(\mathrm{Vit} \mathrm{D}+$ ) or vitamin $\mathrm{D}_{3}$-deficient diets (VitD-) (resp.) until 8 weeks of age. The expression of (a) CCR4 and (b) CCR10 was measured on $\mathrm{CD} 3+\mathrm{CD} 4+\mathrm{CD} 25+$ Foxp3+ cells in the skin, SDLN, lungs, and ADLN, with cells from vitamin $\mathrm{D}_{3}$-replete and vitamin $\mathrm{D}_{3}$-deficient mice shown in blue and black, respectively (unstained $=$ red shaded). Data are representative of two experiments.

$\mathrm{T}_{\text {Eff }}$ cells: Effector T cells

MLN: $\quad$ Mesenteric lymph nodes

$\mathrm{T}_{\text {Reg }}$ cells: Regulatory T cells

SDLN: Skin-draining lymph nodes

VDBP: Vitamin D-binding protein.

\section{Competing Interests}

The authors declare that they have no competing interests.

\section{Acknowledgments}

The authors thank Dr. Bree Foley for her technical assistance with cell sorting and Associate Professor Michele Grimbaldeston for advice on performing the biphasic ear swelling assay. This research was supported by the BrightSpark Foundation, Telethon Kids Institute, University of Western Australia, and Health Department of Western Australia.

\section{References}

[1] B. Muehleisen and R. L. Gallo, "Vitamin D in allergic disease: shedding light on a complex problem," Journal of Allergy and Clinical Immunology, vol. 131, no. 2, pp. 324-329, 2013.

[2] R. M. Lucas, S. Gorman, S. Geldenhuys, and P. H. Hart, "Vitamin D and immunity," F1000Prime Reports, vol. 6, article 118, 2014.

[3] A. C. Ross, C. L. Taylor, A. L. Yaktine, and H. B. Del Valle, Eds., Dietary Reference Intakes for Calcium and Vitamin D, The National Academies Press, Washington, DC, USA, 2011.

[4] M. F. Holick, N. C. Binkley, H. A. Bischoff-Ferrari et al., "Evaluation, treatment, and prevention of vitamin D deficiency: an Endocrine Society clinical practice guideline," The Journal of Clinical Endocrinology \& Metabolism, vol. 96, no. 7, pp. 19111930, 2011.

[5] J. S. Adams and M. Hewison, "Extrarenal expression of the 25hydroxyvitamin D-1-hydroxylase," Archives of Biochemistry and Biophysics, vol. 523, no. 1, pp. 95-102, 2012. 
[6] U. C. Bang, L. Brandt, T. Benfield, and J.-E. B. Jensen, "Changes in 1,25-dihydroxyvitamin D and 25-hydroxyvitamin D are associated with maturation of regulatory $\mathrm{T}$ lymphocytes in patients with chronic pancreatitis: a randomized controlled trial," Pancreas, vol. 41, no. 8, pp. 1213-1218, 2012.

[7] S. Gorman, M. A. Judge, and P. H. Hart, "Immune-modifying properties of topical vitamin D: focus on dendritic cells and T cells," The Journal of Steroid Biochemistry and Molecular Biology, vol. 121, no. 1-2, pp. 247-249, 2010.

[8] S. Gorman, M. A. Judge, and P. H. Hart, "Topical 1,25dihydroxyvitamin D3 subverts the priming ability of draining lymph node dendritic cells," Immunology, vol. 131, no. 3, pp. 415425, 2010.

[9] S. Gorman, L. Alexandra Kuritzky, M. A. Judge et al., “Topically applied 1,25-dihydroxyvitamin $\mathrm{D}_{3}$ enhances the suppressive activity of $\mathrm{CD} 4{ }^{+} \mathrm{CD} 25^{+}$cells in the draining lymph nodes," The Journal of Immunology, vol. 179, no. 9, pp. 6273-6283, 2007.

[10] M. Ghoreishi, P. Bach, J. Obst, M. Komba, J. C. Fleet, and J. P. Dutz, "Expansion of antigen-specific regulatory T cells with the topical vitamin D analog calcipotriol," The Journal of Immunology, vol. 182, no. 10, pp. 6071-6078, 2009.

[11] L. E. Jeffery, A. M. Wood, O. S. Qureshi et al., "Availability of 25-hydroxyvitamin D3 to APCs controls the balance between regulatory and inflammatory $\mathrm{T}$ cell responses," Journal of Immunology, vol. 189, no. 11, pp. 5155-5164, 2012.

[12] S. Gorman, M. A. Judge, and P. H. Hart, "Gene regulation by 1, 25-dihydroxyvitamin $\mathrm{D}_{3}$ in CD4+CD25+ cells is enabled by IL-2," Journal of Investigative Dermatology, vol. 130, no. 10, pp. 2368-2376, 2010.

[13] R. Kundu, B. M. Chain, A. K. Coussens, B. Khoo, and M. Noursadeghi, "Regulation of CYP27B1 and CYP24A1 hydroxylases limits cell-autonomous activation of vitamin $\mathrm{D}$ in dendritic cells," European Journal of Immunology, vol. 44, no. 6, pp. 17811790, 2014.

[14] H. Sigmundsdottir, J. Pan, G. F. Debes et al., "DCs metabolize sunlight-induced vitamin D3 to 'program' T cell attraction to the epidermal chemokine CCL27," Nature Immunology, vol. 8, no. 3, pp. 285-293, 2007.

[15] J. Smolders, M. Thewissen, E. Peelen et al., "Vitamin D status is positively correlated with regulatory $\mathrm{T}$ cell function in patients with multiple sclerosis," PLoS ONE, vol. 4, no. 8, Article ID e6635, 2009.

[16] E. S. Chambers, A. M. Nanzer, D. F. Richards et al., "Serum 25dihydroxyvitamin D levels correlate with $\mathrm{CD}^{+}{ }^{+}$Foxp $^{+}{ }^{+}$T-cell numbers in moderate/severe asthma," The Journal of Allergy and Clinical Immunology, vol. 130, no. 2, pp. 542-544, 2012.

[17] H. Maalmi, A. Berraies, E. Tangour et al., "The impact of vitamin D deficiency on immune T cells in asthmatic children: a case-control study," Journal of Asthma and Allergy, vol. 5, pp. 1119, 2012.

[18] B. Terrier, F. Jehan, M. Munteanu et al., "Low 25-hydroxyvitamin $\mathrm{D}$ serum levels correlate with the presence of extrahepatic manifestations in chronic hepatitis C virus infection," Rheumatology, vol. 51, no. 11, pp. 2083-2090, 2012.

[19] G. Bock, B. Prietl, J. K. Mader et al., "The effect of vitamin $\mathrm{D}$ supplementation on peripheral regulatory $\mathrm{T}$ cells and $\beta$ cell function in healthy humans: a randomized controlled trial," Diabetes/Metabolism Research and Reviews, vol. 27, no. 8, pp. 942-945, 2011.
[20] E. Zold, P. Szodoray, J. Kappelmayer et al., "Impaired regulatory T-cell homeostasis due to vitamin D deficiency in undifferentiated connective tissue disease," Scandinavian Journal of Rheumatology, vol. 39, no. 6, pp. 490-497, 2010.

[21] W. Royal III, Y. Mia, H. Li, and K. Naunton, "Peripheral blood regulatory $\mathrm{T}$ cell measurements correlate with serum vitamin D levels in patients with multiple sclerosis," Journal of Neuroimmunology, vol. 213, no. 1-2, pp. 135-141, 2009.

[22] K. Weisse, S. Winkler, F. Hirche et al., "Maternal and newborn vitamin D status and its impact on food allergy development in the German LINA cohort study," Allergy, vol. 68, no. 2, pp. 220-228, 2013.

[23] F. Baeke, H. Korf, L. Overbergh et al., "The vitamin D analog, TX527, promotes a human $\mathrm{CD} 4{ }^{+} \mathrm{CD} 25^{\text {high }} \mathrm{CD} 127^{\text {low }}$ regulatory $\mathrm{T}$ cell profile and induces a migratory signature specific for homing to sites of inflammation," The Journal of Immunology, vol. 186, no. 1, pp. 132-142, 2011.

[24] A.-L. Khoo, H. J. P. M. Koenen, L. Y. A. Chai et al., "Seasonal variation in vitamin $\mathrm{D}_{3}$ levels is paralleled by changes in the peripheral blood human T cell compartment," PLOS ONE, vol. 7, no. 1, Article ID e29250, 2012.

[25] A.-L. Khoo, H. J. P. M. Koenen, M. Michels et al., "High-dose vitamin $\mathrm{D}_{3}$ supplementation is a requisite for modulation of skin-homing markers on regulatory $\mathrm{T}$ cells in HIV-infected patients," AIDS Research and Human Retroviruses, vol. 29, no. 2, pp. 299-306, 2013.

[26] G. Kim and J. Bae, "Vitamin D and atopic dermatitis: a systematic review and meta-analysis," Nutrition, vol. 32, no. 9, pp. 913-920, 2016.

[27] S. Gorman, D. H. W. Tan, M. J. M. Lambert, N. M. Scott, M. A. Judge, and P. H. Hart, "Vitamin $\mathrm{D}_{3}$ deficiency enhances allergen-induced lymphocyte responses in a mouse model of allergic airway disease," Pediatric Allergy and Immunology, vol. 23, no. 1, pp. 83-87, 2012.

[28] S. Gorman, C. E. Weeden, D. H. W. Tan et al., "Reversible control by vitamin $\mathrm{D}$ of granulocytes and bacteria in the lungs of mice: an ovalbumin-induced model of allergic airway disease," PLoS ONE, vol. 8, no. 6, Article ID e67823, 2013.

[29] S. Geldenhuys, P. H. Hart, R. Endersby et al., "Ultraviolet radiation suppresses obesity and symptoms of metabolic syndrome independently of vitamin D in mice fed a high-fat diet," Diabetes, vol. 63, no. 11, pp. 3759-3769, 2014.

[30] M. W. Clarke, R. C. Tuckey, S. Gorman, B. Holt, and P. H. Hart, "Optimized 25-hydroxyvitamin D analysis using liquidliquid extraction with 2D separation with LC/MS/MS detection, provides superior precision compared to conventional assays," Metabolomics, vol. 9, no. 5, pp. 1031-1040, 2013.

[31] L. J. Black, D. Anderson, M. W. Clarke, A.-L. Ponsonby, and R. M. Lucas, "Analytical bias in the measurement of serum 25-hydroxyvitamin D concentrations impairs assessment of vitamin D status in clinical and research settings," PLoS ONE, vol. 10, no. 8, Article ID e0135478, 2015.

[32] A. Dudeck, J. Dudeck, J. Scholten et al., "Mast cells are key promoters of contact allergy that mediate the adjuvant effects of haptens," Immunity, vol. 34, no. 6, pp. 973-984, 2011.

[33] P. Saint-Mezard, M. Krasteva, C. Chavagnac et al., "Afferent and efferent phases of allergic contact dermatitis (ACD) can be induced after a single skin contact with haptens: evidence using a mouse model of primary ACD," Journal of Investigative Dermatology, vol. 120, no. 4, pp. 641-647, 2003.

[34] S. Gorman, M. A. Judge, J. T. Burchell, D. J. Turner, and P. H. Hart, "1,25-Dihydroxyvitamin $\mathrm{D}_{3}$ enhances the ability of 
transferred $\mathrm{CD}^{+} \mathrm{CD}^{+} 5^{+}$cells to modulate $\mathrm{T}$ helper type 2driven asthmatic responses," Immunology, vol. 130, no. 2, pp. 181-192, 2010.

[35] J. Waithman, R. S. Allan, H. Kosaka et al., "Skin-derived dendritic cells can mediate deletional tolerance of class I-restricted self-reactive T cells," The Journal of Immunology, vol. 179, no. 7, pp. 4535-4541, 2007.

[36] J. M. Weiss, A. M. Bilate, M. Gobert et al., "Neuropilin 1 is expressed on thymus-derived natural regulatory $\mathrm{T}$ cells, but not mucosagenerated induced Foxp $3^{+} \mathrm{T}$ reg cells," The Journal of Experimental Medicine, vol. 209, no. 10, pp. 1723-1742, 2012.

[37] C.-M. Sun, J. A. Hall, R. B. Blank et al., "Small intestine lamina propria dendritic cells promote de novo generation of Foxp3 $\mathrm{T}$ reg cells via retinoic acid," Journal of Experimental Medicine, vol. 204, no. 8, pp. 1775-1785, 2007.

[38] R. C. Malley, H. K. Muller, M. Norval, and G. M. Woods, "Vitamin D3 deficiency enhances contact hypersensitivity in male but not in female mice," Cellular Immunology, vol. 255, no. 1-2, pp. 33-40, 2009.

[39] S. Yang, C. Smith, J. M. Prahl, X. Luo, and H. F. DeLuca, "Vitamin D deficiency suppresses cell-mediated immunity in vivo," Archives of Biochemistry and Biophysics, vol. 303, no. 1, pp. 98106, 1993.

[40] E. Galli, L. Rocchi, R. Carello, P. G. Giampietro, P. Panei, and P. Meglio, "Serum Vitamin D levels and Vitamin D supplementation do not correlate with the severity of chronic eczema in children," European Annals of Allergy and Clinical Immunology, vol. 47, no. 2, pp. 41-47, 2015.

[41] A. Y. Hershko, N. Charles, A. Olivera, D. Alvarez-Errico, and J. Rivera, "Cutting edge: persistence of increased mast cell numbers in tissues links dermatitis to enhanced airway disease in a mouse model of atopy," The Journal of Immunology, vol. 188, no. 2, pp. 531-535, 2012.

[42] Z. Urry, E. S. Chambers, E. Xystrakis et al., "The role of $1 \alpha, 25$-dihydroxyvitamin D3 and cytokines in the promotion of distinct Foxp $3^{+}$and IL- $10^{+} \mathrm{CD} 4^{+} \mathrm{T}$ cells," European Journal of Immunology, vol. 42, no. 10, pp. 2697-2708, 2012.

[43] E. H. Mann, E. S. Chambers, Y.-H. Chen, D. F. Richards, and C. M. Hawrylowicz, " $1 \alpha, 25$-dihydroxyvitamin D3 acts via transforming growth factor- $\beta$ to up-regulate expression of immunosuppressive CD73 on human CD $4^{+}$Foxp $3^{-}$T cells," Immunology, vol. 146, no. 3, pp. 423-431, 2015.

[44] V. L. de Oliveira, R. R. M. C. Keijsers, P. C. M. van de Kerkhof et al., "Humanized mouse model of skin inflammation is characterized by disturbed keratinocyte differentiation and influx of IL-17A producing T cells," PLoS ONE, vol. 7, no. 10, Article ID e45509, 2012.

[45] M. Carretero, S. Guerrero-Aspizua, N. Illera et al., "Differential features between chronic skin inflammatory diseases revealed in skin-humanized psoriasis and atopic dermatitis mouse models," Journal of Investigative Dermatology, vol. 136, no. 1, pp. 136145, 2016. 


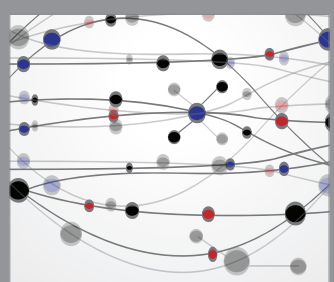

The Scientific World Journal
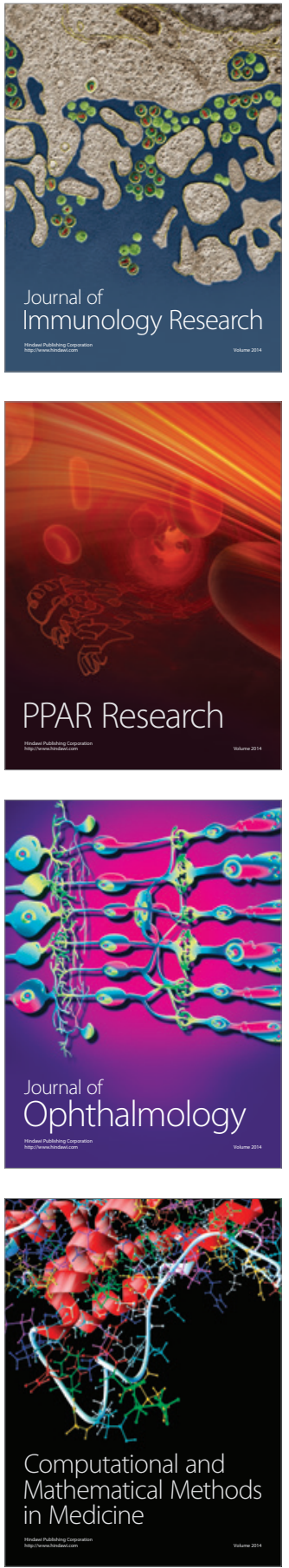

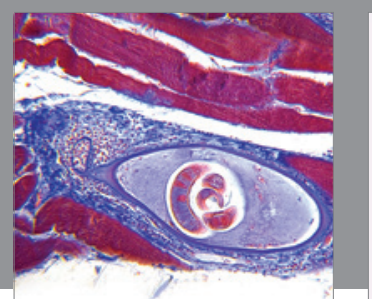

Gastroenterology Research and Practice

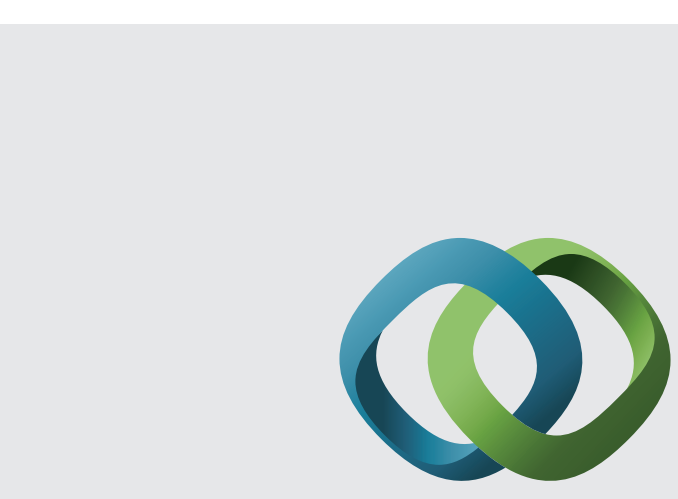

\section{Hindawi}

Submit your manuscripts at

http://www.hindawi.com
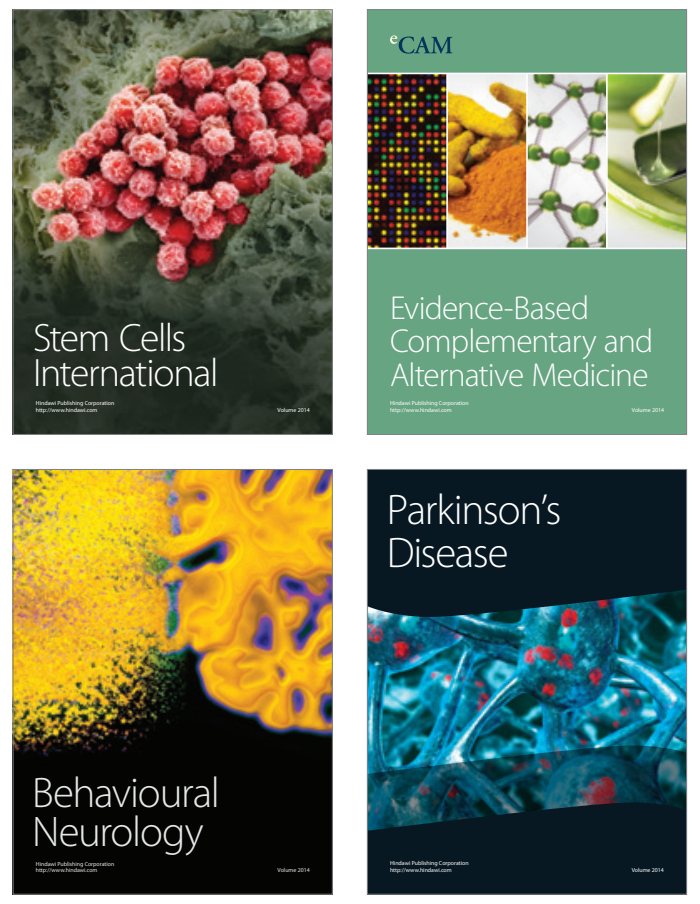
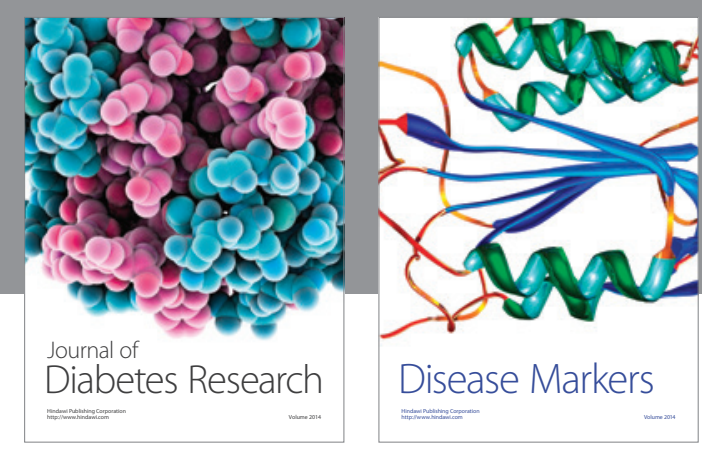

Disease Markers
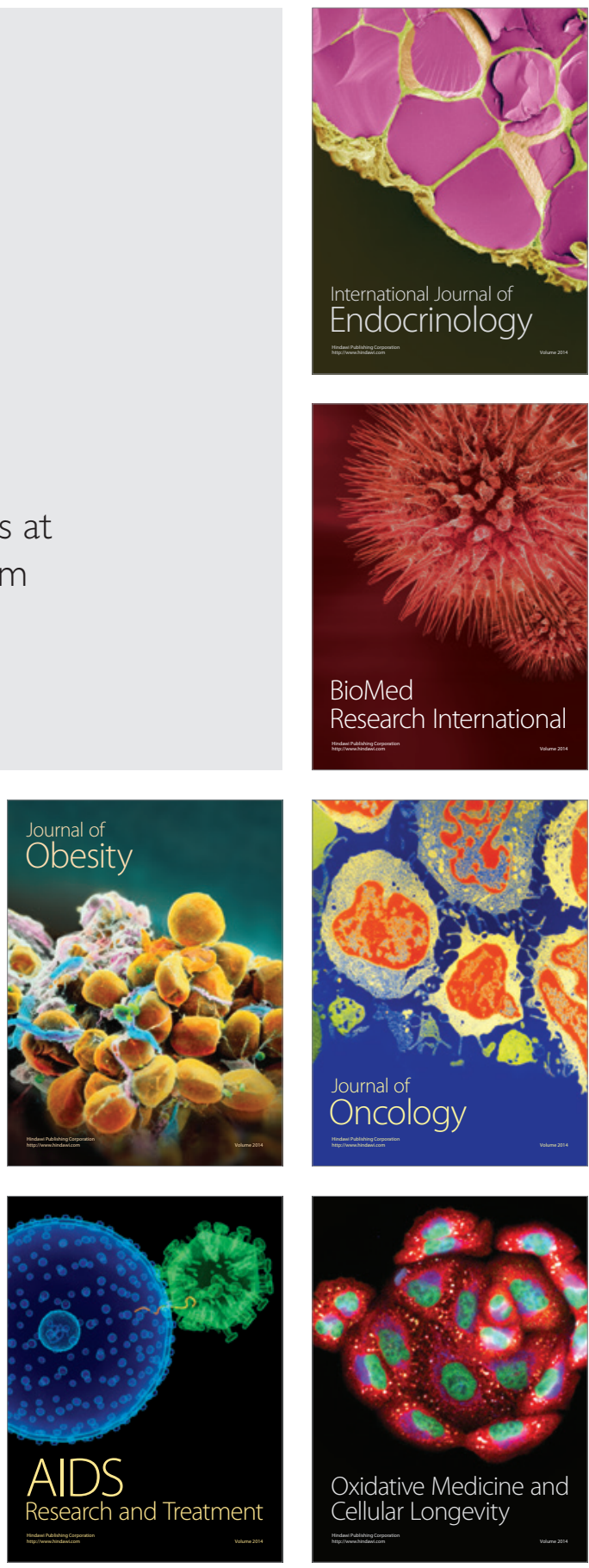